\title{
COMMENTS
}

\section{INSIDER LIABILITY UNDER SECURITIES EXCHANGE ACT RULE 10b-5: THE CADY, ROBERTS DOCTRINE}

Ever since the development of the large, publicly-traded corporation, the prevention of fraud in securities trading has been a major preoccupation of American courts and legislatures. ${ }^{1}$ The halting efforts of common-law courts to raise standards of fair dealing by corporate insiders from the slough into which they had fallen in the early years of this century ${ }^{2}$ were greatly expanded by the wave of reform legislation following the stock market crash of 1929 . However, the elaborate and far-ranging scheme of regulation that has developed under the securities legislation of the thirties should not obscure the common-law background of many of the statutory reforms. This is particularly true of those reforms relating to misrepresentation and nondisclosure by corporate insiders trading in securities of their companies. In this area the courts have led the way and have laid the groundwork for later statutes and administrative decisions which on their face seem drastic. 3

1 LOSS, SECURITIES REguLATION (2d ed. 1961) [hereinafter cited as Loss] is the controlling work in this field. See Ferber, Conflicts of Interest in Reorganization Proceedings Under the Public Utility Holding Company Act of 1935 and Chapter X of the Bankruptcy Act, 28 Gro. WASH. L. REV. 319 (1959); Kaplan, Conflict of Interests: Corporate Directors, 50 ILL. BAR J. 1072 (1962); Latty, The Aggrieved Buyer or Seller or Holder of Shares in a Close Corporation Under the S.E.C. Statutes, 18 LAw \& ConTEMP. PROB. 505 (1953); North, Implied Liability Cases Under the Federal Securities Laws, Corporate Practice Commentator, May 1962, p. 1; Windels, Our Securities Market-Some S.E.C. Problems and Techmiques, 8 N.Y.L.F. 169 (1962); Comment, Fiduciary Duties: Application of S.E.C. Rule X-10B-5, 39 CaIIF. L. REv. 429 (1951); Comment, The Prospects of Rule X-10B-5: An Emerging Remedy for Defrauded Investors, 59 Y ALE L.J. 1120 (1950).

2 It has been observed that at early common law corporate managements were trustees for shareholders who were cestuis according to their property interest. BERLE, STUDIES IN tHe LAW OF CORPoRATION FINANCE 186 (1928) [hereinafter cited as BerLe]. $C f$. Gray v. Portland Bank, 3 Mass. 364 (1807). The later common-law revival of this view rested on other, more dubious, authority. See the leading case of Oliver v. Oliver, $118 \mathrm{Ga} .362,45$ S.E. 232 (1903), citing Jackson v. Ludeling, 88 U.S. (21 Wall.) 616 (1874) (mortgage purchasing prejudicing bondholders) and 2 POMEROY, EQUTTX JURISPRUDENCE $\$ 1090$ (2d ed. 1901) (cases based on corporate waste and ultra vires acts).

3 Compare Oliver v. Oliver, supra note 2, with Securities Exchange Act of 1934, § 10(b), 48 Stat. 891, 15 U.S.C. $\$ 78$ (b) (1958). Compare In re Paramount Publix Corp., 12 F. Supp. 823 (S.D.N.Y. 1935) and In re Republic Gas Corp., 35 F. Supp. 300 (S.D.N.Y. 1936), with Bankruptcy Act $\$ 249,52$ Stat. 901 (1938), 11 U.S.C. $\$ 649$ (1958), and Public Utility Holding Company Act, Rule 62, 17 C.F.R. \$250.62 (1949). "As judges we are entitled to a sense of gratification that the Common Law has been able to make so substantial a contribution to the development of the administrative law of this field." SEC v. Chenery Corp., 318 U.S. 80, 98 (1942) (Black, J., dissenting). 
The recent case of In re Cady, Roberts \& Co.4 appears to presage a dramatic expansion of the scope of the anti-fraud provisions of Exchange Act rule 10b-5.5 The decision, described by the Chairman of the Commission as "a case of first impression and one of signal importance in our administration of the federal securities acts," involved the activities of a broker, Gintel, who sold out his discretionary accounts after receiving non-public dividend information given him in good faith by a director of the corporation who was also a member of the same brokerage firm. The Commission accepted an offer of settlement by the brokerage firm and suspended the offending broker from trading for a period of twenty days. 6

The decision is important for several reasons. The Commission clearly established that nondisclosure was an "act, practice or course of business" operating "as a fraud or deceit" within the meaning of clause 3 of rule 10b-5. It held that the rule could reach nondisclosures by persons who are not "insiders" at common law or by the terms of other sections of the Exchange Act, and that a duty of disclosure was owed even in sales to unidentified persons on a public exchange. The Commission also refused to consider a broker's fiduciary responsibility to his discretionary accounts as a defense to $10 \mathrm{~b}-5$ prosecution. Finally, it disclosed for the first time an awareness of the importance of the development of implied civil liability, observing that "despite the decline in importance of a 'federal rule' in the light of Erie R. Co. v. Tompkins, the securities acts may be said to have generated a wholly new and far-reaching body of federal corporation law."

The implications of the decision are far reaching. In view of the wide range of transactions to which the Exchange Act is applicable, any expansion of traditional concepts of insider liability is of great importance to American corporation law. This comment will appraise the legal basis for such expansion and the possible limitations that may or should be placed upon it.

${ }^{4}$ SEC Securities Exchange Act Release No. 6668, Nov. 8, 1961. The case has been widely noted. See S.E.C. Problems OF CoNTrolling SHAREHolders AND IN UNDERWRITINGS 131-56 (Israels ed. 1962); Daum \& Phillips, The Implications of Cady Roberts, 17 Bus. LAw. 939 (1962); Kaplan, supra note 1; Comment, 62 Colum. L. Rev. 735 (1962); Comment, 71 Yale L.J. 736 (1962); Note, 75 Harv. L. Rev. 1449 (1962); Note, 60 Mich. L. Rev. 651 (1962); Note, 36 ST. JohN's L. REv. 378 (1962); Note, 9 U.C.L.A. L. REv. 731 (1962); Note, 16 U. Miam L. Rev. 474 (1962); Note, 48 VA. L. Rev. 398 (1962). See also note 156 infra.

5 The rule, 17 C.F.R. $\$ 240.10$ b-5 (1949), provides: "It shall be unlawful for any person, directly or indirectly, by the use of any means or instrumentality of interstate commerce, or of the mails, or of any facility of any national securities exchange, (a) to employ any device, scheme, or artifice to defraud, (b) to make any untrue statement of a material fact or to omit to state a material fact necessary in order to make the statements made, in the light of the circumstances in which they were made, not misleading, or (c) to engage in any act, practice, or course of business which operates or would operate as a fraud or deceit upon any person, in connection with the purchase or sale of any security."

6 Thus, it should be noted, the case is not subject to appeal. One commissioner would have refused the offer of settlement and imposed a more severe sanction. Both Cady, Roberts and Gintel had been disciplined by the New York Stock Exchange after the transaction took place in 1959. 
1. Facts subject to disclosure.-At common law, insiders theoretically were held liable only for positive misrepresentations of fact, although relief was sometimes granted where there was a great disparity of knowledge or intelligence between an insider and an exploited shareholder. ${ }^{7}$ An aggrieved shareholder relying on misrepresentation by an insider might have an action for rescission or for deceit. The rescission remedy required the prompt tendering back of the security purchased and hence was of limited usefulness. An action for deceit would lie only when a causal connection between the misrepresentation and loss could be shown and requirements of proof were hence severe. 8 The unsatisfactory state of the early common-law remedies led a number of courts to grant relief for mere nondisclosure in cases where a glaring inequity presented itself, thus creating "majority,"9 "minority," and "special circumstances" rules relating to such liability. The "special circumstances" leading courts to grant relief for nondisclosure were numerous and varied, prompting some to observe that a "majority rule" state was a state in which no case involving glaring inequities had as yet arisen, whereas states adhering to a strict fiduciary view did so only because the facts of the first case there arising demanded special relief. 10 While this view understates the importance of the theory of liability applied by the courts, 11 it does have some validity because of the gradual movement of the courts toward stricter standards of liability. 12 The so-called "special-facts" courts have been willing to grant relief in cases where a director sought out a shareholder to buy stock, where a director and stockholders were the only shareholders, where the director was a majority shareholder, where the corporation was inactive, where there was an agency

7 See Prosser, Torts 532-36 (2d ed. 1955); Tyler v. Savage, 143 U.S. 79, 98 (1892); Stewart v. Wyoming Cattle Ranche Co., 128 U.S. 383 (1888).

8 Reliance was required even under a strict fiduciary view. Steinfeld v. Nielsen, 12 Ariz. 381, 100 Pac. 1094 (1909). An action for rescission for misrepresentation was subject to the usual contract defenses, including waiver, and, most important, lack of privity. 3 WILLISTON, SALES $\$ \$ 636 \mathrm{a}, 636 \mathrm{~b}$ (rev. ed. 1948). A deceit action required proof of scienter, though literal privity was not required under the rule of Ultramares Corp. v. Touche, 255 N.Y. 170, 174 N.E. 441 (1931). See also Cheney v. Dickinson, 172 Fed. 109 (7th Cir. 1909). These cases suggest that an action for deceit could conceivably lie in connection with an exchange transaction where a duty was owed to a particular class of purchasers, e.g., where a prospectus contains misrepresentations. See notes $142,144,152$ infra.

9 Board of Comm'rs of Tippecanoe County v. Reynolds, 44 Ind. 509 (1873); Connolly v. Shannon, 105 N.J. Eq. 155, 147 Atl. 234 (Ch. 1929); Carpenter v. Danforth, 52 Barb. 581 (N.Y. Sup. Ct. 1868), are leading cases reflecting the majority view. See also Percival v. Wright, [1902] 2 Ch. 421.

10 Note, 14 MnN. L. Rev. 530 (1930).

11 See Connolly v. Shannon, 105 N.J. Eq. 155, 147 Atl. 234 (Ch. 1929) (majority rule applied despite special circumstances); Benedict v. Rue, 260 F.2d 97 (5th Cir. 1958) (minority rule applied where no special circumstances).

12 See, e.g., Hobart v. Hobart Estate Co., 26 Cal. 2d 412, 159 P.2d 958 (1945) (special circumstances rule adopted) overruling Ryder v. Bamburger, 172 Cal. 791, 158 Pac. 753 (1916); Note, 19 So. Cal. L. Rev. 32 (1945). See also Agatucci v. Corradi, 327 Ill. App. 153, 63 N.E.2d 630 (1945). 
or joint venture relationship between a director and shareholders, 13 and where there was an anticipated merger, consolidation, or dissolution. ${ }^{14}$ Cases involving an expected sale of corporate assets are less clear, ${ }^{15}$ some "special-facts" courts taking great pains to distinguish "between a situation where, at the time of the stock purchase, there is an assured sale at a price that enhances the value of the stock and a situation where only the possibility of sale exists." 16 There is also a division of authority as to whether disclosure of the identity of an insider purchasing through a straw man is required.17

The "special-facts" cases are in some respects analogous to common-law cases imposing a duty on sellers of chattels to disclose defects where the parties are unequally situated.18 Where this inequality creates a misapprehension that goes to the heart of the nature of the thing traded for, relief is granted at common law. The duty of disclosure is not a fiduciary one since the common-law rule "seems to be that a concealment or misrepresentation as to extrinsic facts which affect the market price of the thing sold is not fraudulent while the same concealment of defects in the articles themselves would be fraudulent." 19 The "special-facts" courts apparently take the view that concealment of information about a major structural change in a corporation goes to a defect in the security itself. 20 While failure to disclose inside dividend information has not as yet been held to constitute a "special fact" by any

1314 MINN. L. REv. 530, 533 (1930).

14 Buckley v. Buckley, 230 Mich. 504, 202 N.W. 955 (1925).

15 Compare Strong v. Repide, 213 U.S. 419 (1909) (liability where preliminary sale negotiations), with Hooker v. Midland Steel Co., 215 Ill. 444, 74 N.E. 445 (1905) (no liability).

16 James Blackstone Memorial Library Ass'n v. Gulf, Mobile \& Ohio R.R., 264 F.2d 445, 451 (7th Cir.), cert. denied, 361 U.S. 815 (1959).

17 Disclosure of identity was required in Broffe v. Horton, 172 F.2d 489 (2d Cir. 1949) (common law); SEC v. Bennett \& Co., CCH Fed. Sec. L. Rep. \{191,172 (D.N.J. Aug. 13, 1962) (rule 10b-5); Taylor v. Wright, 69 Cal. App. 2d 371, 159 P.2d 980 (1945); Barnes v. F. \& W. Lumber Co., 205 Ore. 553, 581-88, 287 P.2d 929, 942-45 (1955); Fisher v. Budlong, 10 R.I. 525 (1893); Gadsden v. Bennetto, 23 Man. 33, 36, 9 D.L.R. 719, 720-21 (1913); Allen v. Hyatt, 3 Ont. Weekly N. 1401, 8 D.L.R. 79 (1912), aff'd, 17 D.L.R. 7 (1914) (common law). See also Strong v. Repide, 213 U.S. 419 (1909); George v. Ford, 36 App. D.C. 315 (1911). Cf. Nichol v. Sensenbrenner, 220 Wis. 165, 263 N.W. 650 (1936) (reorganization trustee liable). But compare Fischer v. Guaranty Trust Co., 259 App. Div. 176, 18 N.Y.S.2d 328 (1940), aff'd 285 N.Y. 679, 34 N.E.2d 379 (1941); Connelly v. Balkwill, 174 F. Supp. 49, 54 (N.D. Ohio 1959). See also Carpenter v. Danforth, 52 Barb. 581 (N.Y. Sup. Ct. 1868). See Conant, Duties of Disclosure of Corporate Insiders Who Purchase Shares, 46 CoRNelL L.Q. 53, 57-58 (1961): "The policy of brokers of listed and over-the-counter securities to guard the secrecy of their customer lists would probably result in prospective sellers' brokers refusing to reveal sellers' names. A rule requiring disclosures would effectively bar stock purchases by officers and directors except from their corporations." It would seem, however, more reasonable to suppose that brokerage houses would partially revise their disclosure policies rather than forego insider business altogether.

18 E.g., Stewart v. Wyoming Cattle Ranche Co., 138 U.S.3 83 (1888); Grigsby v. Stapleton, 94 Mo. 423, 7 S.W. 421 (1888).

19 Grigsby v. Stapleton, supra note 18; Prosser, op. cit. supra note 7, at 722.

20 There is support for this view at common law. See Tyler v. Savage, 143 U.S. 79 (1892). 
state court adhering to the rule, it too would seem to be a defect going to the heart of an investment security.

It should be noted that, aside from the chattel-sale and "special-facts" cases, a minority of state courts have taken the position that inside information is an asset held by directors in quasi-trusteeship for individual shareholders. 21 Some commentators have gone so far as to consider the relationship a strict trusteeship. 22 Contrary to the dire forecasts of some writers, 23 a fiduciary view has not required the disclosure of mere opinions as to the prospects of a corporation. 24 There are, in fact, suggestions in the minority-state opinions that an insider may be under a fiduciary duty not to disclose private opinions where these will be given unduly authoritative weight by his cestui, 25 though no such rule obtains in "special-facts" jurisdictions.

21 Oliver v. Oliver, 118 Ga. 362, 45 S.E. 232 (1903); Stewart v. Harris, 69 Kan. 498, 77 Pac. 277 (1904); Jacquith v. Mason, 99 Neb. 509, 156 N.W. 1041 (1916); Gadsden v. Bennetto, 23 Man. 33, 9 D.L.R. 719 (1913); 3 FLETCHER, CYCLOPEDIA OF CORPORATIONS $\$ 1168.2$, n. 76.

22 BERLE 180.

${ }^{23}$ E.g., Walker, Duty of Disclosure of a Director Purchasing Stock From His Shareholders, 32 YaLe L.J. 637 (1923).

24 Hacker v. Kyle, 211 Wis. 584, 248 N.W. 134 (1933).

${ }^{25}$ Sluss v. Brown-Crumner Inv. Co., 143 Kan. 14, 18, 53 P.2d 900, 903 (1936). See also Tone v. Halsey, Stuart \& Co., 286 IIl. App. 169, 3 N.E.2d 142 (1936. Cf. SEC Securities Exchange Act Release No. 6721 (Feb. 2, 1962), at p. 3 n. 10 (broker-dealer recommending security to client must disclose lack of essential information about issuer); Alexander Reid \& Co., SEC Securities Exchange Act Release No. 6727 (Feb. 8, 1962); Mac Robbins \& Co., SEC Securities Exchange Act Release No. 6846 (July 11, 1962) (on appeal) (extending Reid rule to salesmen held not entitled to rely on representations by employer); B. Fennekohl \& Co., SEC Securities Exchange Act Release No. 6898 (Sept. 18, 1962); A. J. Caradean \& Co., SEC Securities Exchange Act Release No. 6903 (Oct. 1, 1962). Cf. Stone v. United States, 113 F.2d 70, 75 (6th Cir. 1940); United States v. Schaefer, 299 F.2d 625, 629 (7th Cir.), cert. denied, 370 U.S. 917 (1962); SEC v. Rapp, CCH FED. SEC. L. REP. 91, 162 (2d Cir. July 21, 1962); Charles Hughes \& Co. v. SEC, 139 F.2d 434 (2d Cir. 1943); SEC v. Okin, 137 F.2d 862, 864 (2d Cir. 1943); Ultramares Corp. v. Touche, 255 N.Y. 170, 179, 174 N.E. 441,444 (1931): "The defendants owed to their employer a duty imposed by law to make their certificate without fraud, and a duty growing out of contract to make it with the care and caution proper to their calling. Fraud includes the pretense of knowledge where knowledge there is none." See also Knickerbocker Merchandising Co. v. United States, 13 F.2d 544, 546 (2d Cir. 1926) (L. Hand, J.). But see Berko v. SEC, 297 F.2d 116 (2d Cir. 1961).

The British law relating to "puffing" of securities has hitherto been somewhat ahead of the American. Section 12 of the Prevention of Fraud (Investments) Act, 1939, 2 \& 3 Geo. 6 , c. 16 penalizes "the reckless making of any statement, promise or forecast which is misleading, false, or deceptive." (Emphasis supplied.) The provision was carried over to the Prevention of Fraud (Investments) Act, 1958, 6 \& 7 Eliz. 2, c. 45. The English courts have had difficulty with this language. Compare R. v. Bates, [1952] 2 All E.R. 842 (C.A.) (statute covers "the case where there is a high degree of negligence without dishonesty"), with $\mathrm{R}$. v. Mackinnon, [1959] 1 Q.B. 150 (statute requires dishonesty, but "often ... the only evidence of dishonesty consists of evidence that no grounds exist on which any reasonable man could have believed in the truth of the statement ... juries are not slow in a proper case to draw the inference of fraud"). $C f$. R. v. Grunwald, [1961] 2 Weekly L.R. 606 (C.A.) (dishonesty not required, but no liability for "a statement made as a result of an apparently responsible 
The common-law minority rule must be viewed not as an isolated formalism but as an attempt to restore what has been referred to in a different and more controversial context as "that equality of position between the parties in which liberty of contract begins." 26 The "special-facts" cases have in effect applied this principle to securities transactions. 27 The justification for the use of full disclosure principles in securities transactions must depend on the degree of the inequality of position to be redressed in order to achieve a free bargain between informed parties. The impersonal nature of modern securities exchanges, which allow the possessor of inside information to deal with not one but hundreds of buyers, the opportunities for profitable manipulation and the magnitude of the difference in knowledge between an inside director and an unsophisticated small investor are factors which justify this application of the rule.

To be sure, duties of disclosure imposed by contract law have been sharply criticized, both as applied to chattel sales and in the context of securities trading. "Unequal knowledge," it is said, "is a common characteristic of contract negotiations in an enterprise economy." 28 According to advocates of this view

person having given one the information.... Of course, if one knows facts outside what one has been told, that must be taken into consideration."). An earlier version of the statute which would have penalized a person making "a promise or forecast which he has no reasonable ground for supposing to be likely to be fulfilled or verified" was revised after opposition from the financial community. See 132 EcoNomisr 231 (1938); 133 EcoNomsr 331, 385 (1938); Mannherm, Criminal Justice and Social ReConstruction 123-29 (1946) and the parliamentary debates there cited. Cf. Board of Trade, Report on Share Pushing, CMD. NO. 5539 (1937). On the nonstatutory English law, see Reese River Mining Co. v. Smith, L.R. 4 H.L. 64, 79-80 (1869); Derry v. Peek, 14 App. Cas. 337, 368, 374 (1889); Smith v. Chadwick, 9 App. Cas. 187, 203 (1884); KenNY, OUtLINes of CrImINal Law 252 n.2 (13th ed. 1929).

${ }^{26}$ Coppage v. Kansas, 236 U.S. 1, 27 (1915) (Holmes, J. dissenting). Cf. the language of Speed v. Transamerica Corp., 99 F. Supp. 808, 829 (D. Del. 1951): "The duty of disclosure ... is an attempt to provide some degree of equalization of bargaining position in order that the minority may exercise an informed judgment...." See also B. Fennekohl \& Co., SEC Securities Exchange Act Release No. 6898, p. 6: "The concept of puffing is derived from the doctrine of caveat emptor and arises primarily in the sale of tangibles where it appears that examination by the purchaser may offset exaggerated statements and expressions of opinion by the salesman. It can have little application to the merchandising of securities."

27 See the leading "special-facts" case of Strong v. Repide, 213 U.S. 419, 433 (1909): "The whole transaction gives conclusive evidence of the overwhelming influence defendant had in the course of the negotiations as owner of a majority of the stock and as agent for the other owners, and it is clear that the final consummation was in his hands at all times." But courts have refrained from applying modern doctrines of implied warranty to securities issuers. See Shulman, Civil Liability and the Securities Act, 43 YALE L.J. 227, 230 n.9 (1933). See also the limited nature of the warranties provided by UNIFORM STOCK TRANSFR ACT \$ 11; UNIFORM COMMERCIAL CODE \& 8-306.

28 "The party who has been diligent in reducing some of the market uncertainties to fact is not required to come forth and offer his information to the less diligent." Conant, supra note 17, 56-57. For a defense of full disclosure, see Keeton, Fraud-Concealment and Nondisclosure, 15 TeXas L. Rev. 1 (1936); $c f$. Bower, Actionable MisRepresentation 425-27 (1911). Compare Bower, ACTIONABLE NONDISCLOSURE 308-09, 382-84 (1915). 
no duty other than the duty to avoid fraud and half-truths should be owed to the other party in a contractual transaction. However, the economic validity of this view of contractual relationships seems open to question, since ideals of freedom of trade rather than free competition seem overly dominant.

The advocates of the laissez-faire view recognize the impropriety of the use of inside information by fiduciaries, but regard it as a wrong only to the corporation. Cases like Gadsden v. Bennetto 29 may be cited for the view that inside information is a sort of trust fund held by the directors for the benefit of their corporate cestui. However, this view seems no more satisfactory and no less fictitious than a rule that would charge directors as trustees for individual shareholders. 30

Since the directors to be charged for the corporate benefit are in control of the corporation, an action by the corporation itself is unlikely. Adherents of the strict fiduciary approach thus urge a derivative action by corporate shareholders similar to the proceedings under section 16(b). ${ }^{31}$ However, 16(b) actions rest on a strong statutory mandate providing for the allowance of adequate attorneys' fees. ${ }^{32}$ This incentive to bring suit, an incentive which itself raises questions of legal ethics, ${ }^{33}$ would presumably not be present in any common-law action that might be afforded, and single shareholders would be unlikely to sue simply to recover a diluted interest in the proceeds of a director's transaction. Furthermore, a derivative cause of action against a director could, under this view, be vitiated upon ratification of the transaction by the board of directors, and the ratification thus consummated could not be questioned on the basis that the acts ratified were fraudulent. ${ }^{34}$ Moreover, the strict rule would view purchases by a corporation itself as purely contractual, and would thus require "state and federal statutes aimed at specific wrongs" to

2923 Man. 33, 9 D.L.R. 719 (1913).

${ }^{30}$ And its application gives rise to difficulties and anomalies, as even its proponents recognize. See Conant, supra note 17 , at 75 .

31 Conant, supra note 17, at 67, citing Cook \& Feldman, Insider Trading Under the Securities Exchange Act, 66 HARV. L. REv. 385, 408 (1953), says that $\$ 16(\mathrm{~b})$ "'appears to proceed on the principle that the confidential information which a corporate insider automatically obtains by virtue of his position belongs to the corporation." But the section was designed primarily for the protection of investors. See 2 Loss 1041. Where corporate opportunity is not a factor, "it is difficult to detail any certain injury to a corporation from the fact of active trading in its shares other than that in some way the liquidity and veracity of the market for its shares might have been impaired." Loss also suggests that at times it may be that in preparing the market for his activities the insider has acted in a manner directly detrimental to the interests of the corporation. Yourd, Trading in Securities by Directors, Officers, and Shareholders, 38 Mich. L. REV. 133, 150 (1939).

${ }^{32}$ Smolowe v. Delendo Corp., 136 F.2d 231 (2d Cir.), cert. denied, 320 U.S. 751 (1943).

${ }^{33}$ See Magida v. Continental Can Co., 176 F. Supp. 781, 783 (S.D.N.Y. 1956).

34 Conant, supra note 17 , at 75 , says "one can only conclude that the courts have erred in denying corporate recovery of profits made by officers and directors by speculating in the stock of their corporation without consent of the board of directors." (Emphasis added.) 
reach such transactions. 35 In addition, a view charging a director as trustee for his corporation would give rise to double liability where purchasers or sellers were also accorded a remedy for affirmative misrepresentations. 36

The relationship of rule $10 \mathrm{~b}-5$ to common-law standards presents two problems of interpretation, both of which were explicitly or implicitly dealt with by the SEC in Cady, Roberts. First, a question exists as to whether rule 10b-5 constitutes anything more than a "special-facts" rule, since all the cases that have thus far reached the courts have involved special circumstances of one kind or another. ${ }^{37}$ In the case of Speed $v$. Transamerica, a district court observed, by way of dictum, that

[T]he plan ... to capture the Axton-Fisher inventory by merging, dissolving, or liquidating Axton-Fisher is the crucial finding in this case. ... The non-disclosures of the increased earnings and increased value of the tobacco inventory ... have significance because there was such a plan....

... We have, here, sufficient such reasons in the non-disclosure . . . to support violation of the SEC rule where there has been an express finding of the existence of such a plan. ${ }^{38}$

Supporters of the "special-facts" view can thus validly maintain that this case turned on the question of whether nondisclosure would have infiuenced the seller's judgment, since failure to disclose the inventory market value would, according to the court, have been harmless without the liquidation plan.39

However, the leading case of Kardon v. National Gypsum Co., where the court held that a trust relationship was established by the rule and that the action was thus not analogous to an action for common-law deceit, 40 supports

35 Id. at 65. Accord, Anchor Realty \& Inv. Co. v. Rafferty, 308 Ill. App. 484, 32 N.E.2d 394 (1941), 1 BogerT, TRuSTS AND TRUSTEES 81 (1951). Compare Northern Trust Co. v. Essaness Theatres Corp., 348 Ill. App. 134, 108 N.E.2d 493 (1952). See also note 61 infra.

36 This result has been defended by analogy to arguments relating to double liability under $\$ 16(\mathrm{~b})$ and rule $10 \mathrm{~b}-5$. Conant, supra note 17, at 68, citing Comment, 59 YALE L.J. $1120,1140-42(1950)$. However it is one thing to allow double liability as a matter of statutory construction of $\S 16(\mathrm{~b})$, and quite another to advocate the creation of a new cause of action in disregard of the double liability problems which it raises. It cannot convincingly be said that a defendant has wronged both his corporation and the person with whom he deals in an amount equal to twice the insider's profit, or even in an amount equal to his profit plus the difference between contract price and market value on date of sale. This is even assuming, contrary to some cases, that this conservative measure of fraud damages to the purchaser or seller was used in a case involving unjust enrichment. See ResTATEMENT, RESTITUTION, \$151 (1937).

37 Latty, supra note 1 , at 505.

3899 F. Supp. 808, 828, 830 (E.D. Pa. 1951).

${ }^{39}$ Latty, supra note 1, But see, SEC v. Greenfield, SEC Litigation Releases 302, 333 (E.D. Pa. 1946), where a failure to disclose a permanent discrepancy between actual and book value was held a violation of $10 \mathrm{~b}-5$ even though there was no impending sale.

40 'If the plaintiffs' cause of action were solely for common law deceit, they would of course have to prove a loss as part of their case... There are many decisions to this effect, and the rule is not questioned. They have no application, however, in a case in which the action is not for damages for deceit but is for a share of the profits of the transaction." 73 F. Supp. 798, 802 (E.D. Pa. 1947). 
the view that rule $10 \mathrm{~b}-5$ merely adopted the minority common-law doctrine. In addition, the rule has been applied in a number of cases against brokerage firms where no special circumstances were present, and SEC cases prior to Cady, Roberts adhered to this view. 41

Another problem created by the rule arises from the fact that few of the "special-facts" cases at common law involved clear cases of nondisclosure. Hence, it has been argued that the rule does nothing more than reiterate the common-law rule forbidding half-truths. ${ }^{42}$ However, this argument also seems weak. The dearth of common-law cases involving clear failures to disclose is attributable to the failure of common-law courts to apply the disclosure rule to exchange transactions ${ }^{43}$ rather than to any requirement that the nondisclosure be coupled with a misrepresentation or half-truth. For in closely held corporations, where dealings are face-to-face, it becomes impossible to dissociate nondisclosures and misrepresentations. The language of many cases nonetheless makes clear that nondisclosure is regarded as a separate offense. ${ }^{44}$

Courts have viewed these restrictive interpretations of the rule with distinct lack of sympathy and have repeatedly held that rule $10 \mathrm{~b}-5$ goes beyond the common-law fraud standard of the "special-facts" and "half-truth" cases. 45 Similar holdings have been made with reference to the federal Mail Fraud Act. 46 In construing the rule courts have generally treated subsection 2 as the

41 Hughes v. SEC, 174 F.2d 969 (D.C. Cir. 1959); Charles Hughes \& Co. v. SEC, 139 F.2d 434 (2d Cir. 1943); SEC v. Mueller, SEC Litigation Release No. 264, 268 (E.D. Wis. 1945) (consent decree-failure to disclose net earnings and book value per share); SEC v. Mitchell, SEC Litigation Release No. 288, 291 (N.D. Ohio 1945) (consent decree-failure to disclose market price of stock).

42 Reply Brief for Cady, Roberts \& Co., p. 4. Dawson v. National Life Ins. Co., 176 Iowa 362,157 N.W. 929 (1916) is a case which on its facts supplies no basis for finding that the decision rested on misrepresentations, half-truths, other trust relationships, civil law rules, or the corporate opportunity doctrine. $C f$. Conant, supra note 17 , at $61 \mathrm{nn} .35,37,38$, citing similar cases which can, with effort, be made to rest on other grounds.

43 Cf. Goodwin v. Agassiz, 283 Mass. 358, 186 N.E. 659 (1933) (no liability for misrepresentation in exchange dealings in majority rule state).

44 See Tyler v. Savage, 143 U.S. 79 (1892) (failure to disclose passing of most recent dividend accompanied by half-truth assertions that "the last dividend declared was a $7 \%$ semiannual. The fiscal year ends on the first of June" held ground for recovery. Id. at 81.).

45 See, e.g., Ellis v. Carter, 291 F.2d 270 (9th Cir. 1961): "Section 10(b) speaks in terms of the use of 'any manipulative device or contrivance'. . . . Had Congress intended to limit ... [SEC] authority to regulations prescribing common law fraud, it would probably have said so. We see no reason to go beyond the plain meaning of the word 'any,' indicating that the use of manipulative or deceptive devices or contrivances of whatever kind may be forbidden, to construe the statute as if it read 'any fraudulent' devices." Id. at 274. SEC v. Norris \& Hirschberg, Inc., 177 F.2d 228 (D.C. Cir. 1949).

46 United States v. Groves, 122 F.2d 87, 90 (2d Cir.), cert. denied, 314 U.S. 670 (1941) (failure of officer of corporation to disclose his participation as joint adventurer in sale of stock to corporation). The criminal statute, 18 U.S.C. $\$ 1341$ (1958), proscribes "any scheme or artifice to defraud, or for obtaining money or property by false or fraudulent pretenses, representations, or promises . ..." See also Durland v. United States, 161 U.S. 306, 313 (1896); Deaver v. United States, 155 F.2d 740 (D.C. Cir.), cert. denied, 329 U.S. 766 (1946); United States v. Buchner, 108 F.2d 921 (2d Cir.), cert. denied, 309 U.S. 669 (1940); Kaufmann v. United States, 282 Fed. 776 (3d Cir.), cert. denied, 260 U.S. 735 (1922). 
broadest provision. 47 This seems a curious result, since the subsection makes it unlawful only "to omit to state a material fact necessary in order to make the statements made, in the light of the circumstances in which they were made, not untruthful." The appearance of the word "fraud" in subsection 3, which proscribes "any act, practice, or course of business which operates or could operate as a fraud or deceit upon any person," has led some courts to read the section as merely a codification of the common law, 48 and to strain to bring cases involving "pure" nondisclosures and manipulations by brokers within subsection 2. While the weight of authority thus holds that section 2 at least goes beyond the common-law "special-facts" cases, some courts maintain that it does not, 49 except insofar as it adopts the equitable doctrine of constructive fraud by dispensing with the need for proof of wrongful intent. 50 This view seems defensible since, as we have seen, section 2 finds its roots in the common-law half-truth cases. If, as the Charles Hughes ${ }^{50 a}$ case suggests, the Commission is empowered to go beyond the common-law cases in prohibiting fraud, then section 3 is its logical vehicle, with its broad "act, practice, or course of business" phraseology, and its prohibition not only of conduct which "operates" but of conduct which "would operate" as a fraud or deceit.

47 Ellis v. Carter, 291 F.2d 270, 274 (9th Cir. 1961) (false promise to buyer of voice in management); Hughes v. SEC, 174 F.2d 969 (D.C. Cir. 1949) (broker's failure to disclose profits on sale from inventory); Charles Hughes \& Co. v. SEC, 139 F.2d 434 (2d Cir.), cert. denied, 321 U.S. 486 (1943) (broker's failure to disclose excess commission); Speed v. Transamerica Corp., 99 F. Supp. 808 (D. Del. 1951) (failure to disclose increased inventory valuation where merger planned); Kardon v. National Gypsum Co., 73 F. Supp. 798 (E.D. Pa. 1947) (failure to disclose contemplated sale of assets where question related to sale of stock). But see Kardon v. National Gypsum Co., 83 F. Supp. 613 (E.D. Pa. 1947) (same facts, held within subsection 3); Joseph v. Farnsworth Radio \& Television Corp., 99 F. Supp. 701, 706 (S.D.N.Y. 1951), aff'd, 198 F.2d 883 (2d Cir. 1952) (failure to disclose inventory changes and net losses) (dictum, "at most" within $\$ 3$ alone).

48 Charles Hughes \& Co. v. SEC, supra note 47, at 447; Hughes v. SEC, supra note 47, at 975. This view is supported in Daum \& Phillips, The Implications of Cady, Roberts, 17 Bus. LAw. 939, 943-47 (1962).

49 Connolly v. Balkwill, 174 F. Supp. 49 (N.D. Ohio 1959) (failure to disclose plan for sale of assets). "[T] due duty to speak which is implicit in Rule X 10b-5 arises in those circumstances where a fiduciary or quasi-fiduciary relationship exists, where confidence is reposed or influence acquired . . . . But it cannot be supposed that the rule imposes a duty to speak in all cases involving the purchase or sale of securities irrespective of the relations of the parties or the circumstances under which the transaction is consummated." Id. at 59 . See Mills v. Sarjem Corp., 133 F. Supp. 753, 766-67 (D.N.J. 1955) (no duty of broker under rules $10 \mathrm{~b}-5$ and $15 \mathrm{c}(1)(2)$ to disclose uncertain plan for resale of assets).

50 Connolly v. Balkwill, supra note 49, at 58. The Martin Act in New York has also been construed to dispense with the common-law requirement of scienter, People v. Federated Radio Corp., 244 N.Y. 33, 154 N.E. 655 (1926) (conviction for concealment of damaging information in prospectus where warnings of "speculative" nature of issue were thought sufficient to avoid fraud) (compare N.Y. LAws, ch. 553 (McKinney 1955)), as has the Federal Mail Fraud Act, Foshay v. United States, 68 F.2d 205, 210 (8th Cir. 1933), cert. denied, 291 U.S. 674 (1934). Both these acts are criminal statutes where strict requirements of proof might be expected to apply.

50a 139 F.2d 434 (2d Cir. 1943). 
2. Who must disclose?-The most significant aspect of the Cady, Roberts decision is the Commission's application of rule $10 b-5$ to persons other than officers, directors, and controlling shareholders. In announcing this extension, the Commission observed:

We have already noted that the anti-fraud provisions are phrased in terms of "any person" and that a special obligation has been traditionally required of corporate insiders, e.g., officers, directors, and controlling shareholders. ${ }^{51}$ These three groups, however, do not exhaust the classes of persons upon whom there is such an obligation. Analytically, the obligation rests on two principal elements; first, the existence of a relationship giving access, directly or indirectly, to information intended to be available for a corporate purpose and not for the personal benefit of anyone, and second, the inherent unfairness involved where a party takes advantage of such information knowing it is unavailable to those with whom he is dealing. ... [T] hus our task here is to identify those persons who are in a special relationship with a company and privy to its internal affairs, and thereby suffer correlative duties in trading in its securities.

While the SEC can find support for its position in the literal language of the statute and rule, it has not hitherto stressed the rule's use of the phrase "any person." 52 The rule has, however, been applied to activities of brokers 53 and, in several instances, to fraud perpetrated by outside purchasers of stock. ${ }^{54}$ But

51 There appears to be no common-law minority rule or special-facts case imposing a fiduciary duty on controlling shareholders vis-à-vis individual stockholders. Yourd, supra note 31 , at 139-43. Rather majority stockholders were considered trustees for the shareholders as a whole, Zahn v. Transamerica Corp., 162 F.2d 36 (3d Cir. 1947); Geller v. Transamerica Corp., 53 F. Supp. 625, 630 (D. Del. 1943), aff'd, 151 F.2d 534 (3d Cir. 1945); Sautter v. Fulmer, 258 N.Y. 107, 179 N.E. 310 (1932), or, by application of the so-called "instrumentality" doctrine, trustees to the minority shareholders, Pepper v. Litton, 308 U.S. 295 (1939); Southern Pacific Co. v. Bogert, 250 U.S. 483 (1919). See 3 Loss 1446, n.4.

52 Both $\$ 10(\mathrm{~b})$ of the statute and rule $10 \mathrm{~b}-5$ apply to activities of "any person, directly or indirectly, by the use of any means or instrumentality of interstate commerce, or of the mails, or of any facility of any national securities exchange...." Section 3(a)(9) of the statute provides that "when used in this title, unless the context otherwise requires ... the term 'person' means an individual, a corporation, a partnership, an association, a joint stock company, a business trust, or an unincorporated organization." See Hooper v. Mountain States Securities Corp., 282 F.2d 195, 202 (5th Cir. 1960) ("If an issuing corporation is not within the regulation, it is not because it is not a (person." "). But compare Mills v. Sarjem Corp., 133 F. Supp. 753, 764-65 (D.N.J. 1955) ("The cases imposing a duty on the part of a purchaser of shares of stock to disclose his knowledge of future prospects and plans all involve situations where the purchaser holds a fiduciary position and where the knowledge has been obtained by virtue of an 'inside' position.").

53 Hughes \& Co. v. SEC, 174 F.2d 228 (D.C. Cir. 1949); In the Matter of Van Alstyne, Noel \& Co., 33 S.E.C. 311 (1952); R. D. Bayly \& Co., 19 S.E.C. 773 (1945). All of these cases involved transactions also held violative of $\S 17(\mathrm{a})$ of the Securities Act of 1933 and $\S 15$ (c)(i) of the 1934 act, and rule 10b-5 was applied without discussion. SEC v. Van Loo, SEC Litigation Releases Nos. 940, 945 (W.D. Mich. 1955).

54 See the recent important case of Hooper v. Mountain States Securities Corp., 282 F.2d 195 (5th Cir. 1960) (2-1 decision), criticized in 13 STAN. L. REV. 378 (1960) (fraud by out- 
until recently, discussions of the rule have tended to read into it definitions of an insider contained in section 16(b) and other portions of the act.55

What justifications are there for a further extension of the rule? It seems clear that a literal application of the rule would have little merit. It has been suggested that such an approach to the rule would produce fraud rather than prevent it by leaving transactions of innocent persons open to attack on mere suspicion, or as the result of entrapment.56 Thus some limiting principle is called for and the principle adopted should find some basis in common-law experience.

Both at common law57 and under the Exchange Act, 58 a person acting as an insider's agent in the perpetration of a fraud is liable for nondisclosure. 59 Indeed, one court has gone so far as to observe of such agents that "it would be sufficient if they had merely mailed a letter without knowing its contents or even had merely supplied their stationery, provided that they knew that in so doing they were rendering service essential to or participating in a scheme of

sider as to value of consideration paid for securities). See also SEC Litigation Release No. 397 (April 17, 1947) (mail fraud); SEC Litigation Release No. 499 (Feb. 4, 1949) (customer giving false orders to dealers), cited in Comment, 39 CALIF. L. REV. 429, 434 (1951).

55 Section 16(b) of the act applies to "every person who is directly or indirectly the beneficial owner of more than 10 per centum of any class of any equity security ... or who is a director or an officer of the issuer of such security ...." A controlling shareholder was held within the rule in Speed v. Transamerica Corp., 99 F. Supp. 808, 829 (D. Del. 1951).

563 Loss 1451; Comment, 39 CALIF. L. Rev. 429, 439 (1951).

57 Emory v. Parrott, 107 Mass. 95 (1871) (outside associate of partner purchasing from partnership held jointly and severally liable with partner). Zinc Carbonate Corp. v. First National Bank of Shullsburg, 103 Wis. 125, 131, 79 N.W. 229, 232 (1899) (national bank as outside associate of corporate officer); Lomita Land \& Water Co. v. Robinson, 154 Cal. 36, 46, 97 Pac. 10, 14 (1908) (outside associate of promoter, even though associate was not in league with promoter from the beginning since "it matters not how unequal may have been the assistance rendered"). See Jackson v. Smith, 254 U.S. 586, 589 (Brandeis, J.) (outside associate of receiver); Saville v. Sweet, 234 App. Div. 236, 254 N.Y. Supp. 768 (1932) (outside associate of corporate officers). See also Traer v. Clews, 115 U.S. 528, 534 (1885) (rescission of contract with wife of officer granted on theory that officer was agent for his wife in transaction). Cf. In re Calton Crescent, 173 F.2d 944 (2d Cir.) (Swan, J.), aff'd sub nom. Manufacturers Trust Co. v. Becker, 338 U.S. 304 (1949) (outsiders chargeable with knowledge of officer, who is their agent where they exercise no independent judgment in investment of funds) (dictum).

58 Fry v. Shumaker, 83 F. Supp. 476 (E.D. Pa. 1947) (brokers knowingly participating in fraudulent solicitation scheme liable as co-conspirators or joint tort-feasors at common law and under rule 10b-5); In the Matter of M. S. Wein \& Co., SEC Securities Exchange Act Release No. 3855 (1946) (broker attending meetings of directors prior to fraud); Matter of General Securities Corp., SEC Securities Exchange Act Release No. 3678 (1945) (brokerage license revoked where broker sold out director wife's account after transferring his holdings to her.)

59 But compare In re Franklin Building Co., 178 F.2d 805 (7th Cir. 1949) (2-1 decision), cert. denied sub nom. Simonsen v. Emmerling, 339 U.S. 978 (1950) (refusal to limit to cost pursuant to $\S 212$ of Bankruptcy Act claim on bonds purchased by immediate family of reorganization committeeman at his advice). See also note 99 infra. 
fraud."60 It is likewise clear, both at common law61 and under the Securities Act, 62 that a corporation itself may be held liable for nondisclosure in the purchase or sale of shares, or in their conversion. ${ }^{63}$ More difficult problems arise in connection with transactions involving other persons receiving information: employees, individuals doing business with a corporation, bankers, attorneys, wives and relatives, recipients of "hot tips" and those receiving information from such persons.

Moreover, the broad language of the rule suggests that it might eventually be applied not only to persons possessing undisclosed information about the affairs of a corporation, but also to persons possessing undisclosed information about contemplated manipulated trading of a corporation's stock. ${ }^{64} \mathrm{Sec}$ tion $10($ b), it should be noted, is aimed at "manipulative" as well as "deceptive" devices. Failure to reveal manipulations has already been held by the Commission to be a nondisclosure within the meaning of rule $10 \mathrm{~b}-5,65$ while

60 Fry v. Schumaker, 83 F. Supp. 476 (E.D. Pa. 1947).

61 Northern Trust Co. v. Essaness Theatres, 348 I11. App. 134, 108 N.E.2d 493 (1952); Steven v. Hale-Haas Corp., 249 Wis. 805, 831, 23 N.W.2d 620, 632 (1946) (dictum); 3 Loss 1454. See also the cases where purchase by a corporation benefits its shareholding directors: Wood v. McLean Drug Co., 266 III. App. 5 (1932); Johnson v. Mansfield Hardware Lumber Co., 143 F. Supp. 826 (W.D. La. 1956). Contra Gladstone v. Murray Co., 314 Mass. 584,50 N.E.2d 958 (1943) (director's "duty was to the company for which he was acting and not to the seller of the stock"). BERLE at 187-88, states: "Certain information must be withheld for the best interests of everyone concerned, the interest in concealment being so great as to override the individual interests of the persons buying or selling ... [even though] there is something to be said for the proposition laid down by Horace that a man of blameless life needs no quiver full of arrows for his bow." Percival v. Wright, [1902] 2 Ch. 421, 426 (same view was taken as to disclosures by directors trading for their own account). But see Oliver v. Oliver, 118 Ga. 362, 368, 45 S.E. 232, 234 (1903) (strict disclosure upheld though corporation prejudiced); 14 MINN. L. REV. 530 (1930).

62 Kohler v. Kohler Co., 208 F. Supp. 808, 820 (E.D. Wis. 1962); Northern Trust Co. v. Essaness, 103 F. Supp. 954 (N.D.Ill. 1952); Ward La France, 13 S.E.C. 373 (1943); SEC v. Oils \& Indus., 11 S.E.C. Ann. Rep. 33 (S.D.N.Y. 1945) (director's interests enhanced).

63 Zahn v. Transamerica Corp., 99 F. Supp. 808, 843-50 (D. Del.), aff'd, 162 F.2d 36 (3d Cir. 1947); MacGill v. MacGill, 135 Md. 384, 109 Atl. 72 (1919) (common law); 59 YaLE L.J. 1151 (1950). But see National Supply Co. v. Leland Stanford Univ., 134 F.2d 689, 694 (9th Cir.), cert. denied, 321 U.S. 773 (1943) (no disclosure duty where exchange of shares upon merger).

64 Manipulative practices with reference to securities registered on a national exchange are dealt with by $\S 9$ of the act, and particularly by $\S 9(a)(2)$. But a $\S 10 b-5$ liability for exchange transactions would not completely duplicate $\$ 9(\mathrm{a})$, since $\S 9(\mathrm{e})$ of the act imposes a short limitation period upon $\$ 9$ (a) private actions and allows a court to require an undertaking for the payments of costs of suit. Section 10b-5 imposes no such restrictions.

65 In the case of Barrett \& Co., 9 S.E.C. 319 (1941), the Commission held that the use of a practice prohibited as to registered exchange securities by $\S 9$ (a)(2) constituted a "manipulative, deceptive, or other fraudulent device of contrivance" within the meaning of $\S 15(\mathrm{c})(1)$, and thus extended to all exchange transactions involving brokers. Similar reasoning has been used to justify the promulgation of rule 10b-1, which extends the 9(a) prohibitions to securities exempt from registration on a national exchange. Cases directly applying $10 \mathrm{~b}-5$ include R. L. Emacio \& Co., 35 S.E.C. 191, 199-200 (1953); Adams \& Co., 33 S.E.C. 444, 457 (1952) (manipulation of exchange prices in connection with over-the-counter sale); Halsey Stuart \& Co., 30 S.E.C. 112 (1949) (manipulation of over-the-counter prices); Thornton \& Co., 28 S.E.C. 208, 224-25 (1948). 
court cases arising under section 17(a) have taken this view with reference to over-the-counter sales consummated at a rigged market price. "An offer "at the market," " courts have observed, "must have been understood to imply a price fixed by supply and demand, free from artificial restriction and intentional stimulation." 66 Thus a sale at a price determined by a manipulated market was held to be an actionable "half-truth" of the type proscribed in the common-law chattel cases and under section 2 of 17(a) and rule 10b-5. One might not need to go far from this view to find that a sale on a manipulated market, apart from any express agreement as to a market price standard for a non-market sale, constitutes a fraudulent or deceitful act, practice, or course of business within the meaning of section 3.67

Rule $10 \mathrm{~b}-5$ thus in the long run could supply the answer to one of the Commission's more pressing present problems, that presented by the fund manager or investment adviser who uses his advance knowledge of controlled market movements to earn a profit for his own account. In the recent Capital Gains case, the Second Circuit, in a five to four en banc decision, declined to hold that "scalping" by an investment adviser constituted a fraud upon his client prohibited by sections 206(1) and (2) of the Investment Advisers Act. The court reasoned, not illogically, that if advice to the client were sound and sincere, the adviser's "scalping" activities did not constitute a fraud upon him. 68

66 Coplin v. United States, 88 F.2d 652, 661-64 (9th Cir. 1947); Collins v. United States, 157 F.2d 408 (9th Cir.), cert. denied, 331 U.S. 849 (1946) (conviction for conspiracy to violate $\$ 17(\mathrm{a})$ and mail fraud statute in over-counter activities affirmed; acquittal below as to substantive charge); Otis \& Co. v. SEC, 106 F.2d 579, 583 (6th Cir. 1939) (manipulation of exchange prices in connection with over-the-counter sale); R. J. Koppe v. SEC, 95 F.2d 550 (7th Cir. 1938) (manipulation of exchange prices in connection with over-counter sale).

67 At common law, a third person induced to buy from manipulators at an unfair price had an action for deceit, subject, however, to the difficult requirements of privity and reliance. These requirements were rarely met, save where there was a false representation of a $\S 2$ nature. See Loss 888; Scott v. Brown, Doering, McNab \& Co., 2 Q.B. 724, 734 (1892) (dictum); Bedford v. Bagshaw, 4 H. \& N. 538, 157 Eng. Rep. 951 (Ex. 1859) (recovery allowed market purchaser for misrepresentations as to allocation of shares in obtaining exchange listing), overruled in Peek v. Gurney, L.R. 6 H.L. 377 (1873); Salaman v. Warner, 65 L.T.R. (n.s.) 132 (C.A. 1891). See also Brown v. Werblin, 138 Misc. 29, 244 N.Y. Supp. 209 (Sup. Ct. 1930) (profits of pool not trust fund for injured purchasers in individual representative suit). See Moore \& Wiseman, Market Manipulation and the Exchange Act, 2 U. CHI. L. REv. 46, 70-72 (1934).

68 SEC v. Capital Gains Research Bureau Inc., CCH FED. SEC. L. REP. (2d ed.) I 91,166 (2d Cir. 1961), affirming 191 F. Supp. 897 (S.D.N.Y. 1961) (construing Investment Advisers Act, $\S \S 206(1)$, (2), 15 U.S.C. $80 \mathrm{~b}-6(1)$, (2)). The act makes it unlawful "to employ any device, scheme, or artifice to defraud any client or prospective client . .." or "to engage in any transaction, practice, or course of business which operates as a fraud or deceit upon any client." The district court concluded that "the words 'fraud" and 'deceit' are used in their technical sense" and demanded proof that liquidation of the adviser's account reduced the value of clients' stock. 191 F. Supp. at 898. A court of appeals panel affirmed, distinguishing Cady, Roberts as a case involving inside information, in a 2-1 decision, one judge concurring only in the result. 300 F.2d 745 (2d Cir. 1962). The court made the provocative observation that "the artificial stimulant" of a small firm's advice was dwarfed by "the buying power 
It was not, however, called upon to decide whether the adviser's purchases or sales of stock constituted fraud upon the persons to whom he sold or from whom he bought. This issue was obliquely touched upon in the dissenting opinion by Judge Clark, which observed that

it is the recognition that if investment advisers are to "defraud" anyone it will not be in the normal buyer-seller context which is crucial to this case. For it is in the secondary effects of advice, not in direct dealings, that the real potentials for fraud lie in this field. To reach and prevent that is the purpose of this legislation; defrauding in direct dealings is covered by the earlier acts regulating brokers and dealers. 69

This proposition, however, is not self-evident even in relation to investment advisers, let alone persons who directly manage large funds. If rule $10 \mathrm{~b}-5$ is ultimately to be read in terms close to its "any person" language, and thus be construed as an announcement of standards of fair dealing binding on all market traders, ${ }^{70}$ the fact that the undisclosed information relates to market trading rather than corporate affairs might not preclude liability. In an age of giant mutual and pension funds, it can scarcely be denied that knowledge of future purchases and sales can be as valuable as knowledge of undisclosed corporate developments. But such extensions of the rule will take place, if ever, in the distant future, despite the cases we have mentioned. For the Capital Gains case itself suggests judicial resistance to the use of rules prohibiting fraud and deceit as means of preventing activities that courts have regarded, rightly or wrongly, as manipulative rather than fraudulent in nature.

which comes from pension funds, investment trusts, university and hospital endowments, foundations [and] insurance companies." Id. at 748. The en banc opinion relied primarily on the absence of an express prohibition of manipulative practices in the statute as it stood prior to 1960 . But both majority and dissenting judges overlooked the fact, not strongly urged by the SEC, that what was sought was not an injunction against the adviser's trading itself, but an injunction against his failing to disclose a potentially adverse interest. $C f$. note 17 supra.

69 SEC v. Capital Gains Research Bureau Inc., CCH FED. SEC. L. REP. (2d ed.) I 91,166 (2d Cir. 1961). In the District Court, the Commission abandoned an effort to reach the transaction under the Investment Company Act, but the Exchange Act was not invoked. Compare Windels, Our Securities Markets-Some S.E.C. Problems and Techniques, 8 N.Y.L.F. 169, 185-86 (1962) ("When one has the power to invest large sums, there is always a temptation to use that power to give leverage to a private transaction. . . . There is the temptation to make a personal investment and then bring in fund money to give the particular stock a ride. ... [P]ractices of this sort are a strong indication that the management tolerating them should not be entrusted with the fiduciary role which is the principal thing that a fund sells to its investors."). See also One William Street Fund, 2 CCH BLUE SKY L. REP. I 52,623.03 (quoting Wis. Dept. Securities, Monthly Bulletin, May 1958) (mutual fund required to insert in charter provisions that "(a) the investment adviser may not profit directly or indirectly from sales to or from the portfolio, (b) no member of the Board of Directors or of the investment or portfolio committees of the fund may serve on the Board of Directors of a company in which the investment company holds securities."). $C f$. Wall Street Journal, Nov, 19, 1962, p.4, col. 3 (N.Y. Stock Exchange release on "scalping").

70 See text at note 115 infra. But compare Mills v. Sarjem Corp., 133 F. Supp. 753 (D.N.J. 1955) (outside buyer of stock not obliged to disclose merger plan while acquiring stock). Cf. 2 Loss 1392. 
Rule $10 \mathrm{~b}-5$ thus remains a rule directed primarily against misrepresentations and nondisclosures, rather than against manipulations. Its future significance will be determined by the extent to which the expansion of possible insider liability approaches the literal application of the "any person" rule. It seems clear that the rule will not be literally applied, since the courts appear unwilling to hold that fraud exists apart from some sort of confidential relationship involving tort-feasor and victim. Cady, Roberts does, however, constitute a clean break with the view as to the limitations of the "any person" rule expressed by a representative of the SEC in 1952:

Mr. Byrne: They [SEC] agree $100 \%$ that an insider cannot take advantage of a stockholder of his company in connection with the purchase from him or the sale to him of the company's stock where he has information not known to that man on the other side of the transaction because of his fiduciary obligation to disclose it to him. I do not believe, however, the Commission takes the second and third steps in their current consideration of X10B5, and by second and third steps $I$ mean this: That insider could communicate to an outsider the same information he knows, and the outsider might act on it and unless the Commission had evidence from which they could conclude that the insider was a party in fact to the transaction, either acted in concern with or conspiracy with the outsider, I do not think that they would hold the outsider as being in violation of Rule X10B5; and your third case is what I call the locker-room case . . . where a fellow at the golf club overhears the insider talking to a friend of his and he himself acts on the basis of the information he heard and that case I do not think the Commission would touch at all at this stage of its existence.

Mr. Heller: Would they hold the insider?

Mr. Byrne: They would hold the insider without question in the first case; in the second and third cases they would not hold the outsider who had the inside information, unless they could show a conspiracy or concert of action with the insider, in which event they would hold both of them, and in no event would they hold the locker-room man. ${ }^{11}$

In Cady, Roberts, the Commission goes well beyond the view that a "concert or conspiracy" was necessary to hold an outsider. This is clear since the insider was guilty of no breach of trust, and the Commission's opinion emphasizes that the decision rests on general principles of liability, loosely described in the opinion as "the existence of a relationship" and "inherent unfairness," rather than on the existence of the partnership. The Commission notes that since a fiduciary relationship prohibited a director from trading, "by logical sequence, it should prohibit a partner." The logic of this prohibition is found by the Commission in the rule set forth in the Restatement of Restitution, section 201(2):

71 Peter T. Byrne, Director of the Division of Trading and Exchanges, in Study of the Securities and Exchange Commission. Hearings before a Subcommittee of the House Committee on Interstate and Foreign Commerce, 82d Cong., 2d Sess. Pt. 1, pp. 725-26 (1952). 
Where a fiduciary in violation of his duty to the beneficiary communicates confidential information to a third person, the third person, if he had notice of the violation of duty, holds upon a constructive trust for the beneficiary any profit which he makes through the use of such information. 72

The Restatement provision supplies what is at best a mere verbal analogy which offers no firm authority for the extension of insider liability to a new sphere; for the section is based on the common-law cases involving the receipt of trade secrets in which a person knowingly acquiring a trade secret by virtue of breach of duty or indiscretion of a trusted corporate employee is charged with a trust for the benefit of the corporation. In the securities cases the duty sought runs not to the corporation itself, but rather to the potential purchasers and sellers of its stock. Furthermore, the duty dictates that there must be uniform disclosure, not that there has to be no disclosure. A uniform disclosure of inside information is clearly improper in the ordinary trade secret case, since there the "outsiders" are competitors. In securities cases, a uniform disclosure of information does no harm to the corporation, save in "corporate opportunity" cases or in cases where the information disclosed to traders is a trade secret which would be of value to competitors.

However, the fact that the trade-secret cases do not directly support the adoption of the Cady, Roberts rule does not mean that their principles are valueless in determining how far the new rule may be extended. This is true since the cases proceed on general principles that will prove of far more value in determining the proper reach of insider liability than efforts to extend the rule by successively imposing liability on partners, wives, relatives, and other specific classes of persons.

The trade-secret cases grant relief where information is tortiously acquired or inequitably retained, and deny it where there is independent discovery or analysis of the product. A trade secret is tortiously acquired where a party deliberately induces its disclosure by a fiduciary or contractor in violation of his obligations. Thus in the early case of Tabor v. Hoffman, ${ }^{73}$ where a third person induced a contractor possessing an inventor's machinery patterns to allow him to copy and make use of the patterns, relief was granted even though the same information might eventually have been obtained by analysis of the finished machine itself. Citing master-servant cases involving the obligations of former employees, the court observed that "the defendant

72 SEC Securities Exchange Act Release No. 6668, at 7 n.17, citing RESTATEMENT, RESTITUTION (1937). The Supreme Court declined to charge brokerage partners under $\$ 16(b)$ of the Exchange Act in Blau v. Lehman, 368 U.S. 403 (1962), but this result was compelled by the language of $16(\mathrm{~b})$, which refers only to "officers, directors, and controlling shareholders" and by its restrictive legislative history. See also notes 95 and 96 infra.

73118 N.Y. 30, 23 N.E. 12 (1889), affirming 41 Hun. 5 (1889). See Comment, 64 Harv. L. Rev. 976, 981 (1950). RESTATEMENT, RESTITUTION \$201(2) has been applied in non-tradesecret situations. See, e.g., Midstate Amusement Corp. v. Rivers, 54 F. Supp. 738 (E.D. Wash. 1944). 
had no right to obtain [the trade secret] by unfair means or to use it after it was thus obtained . . . because this discovery may be possible by fair means, it would not justify the use of unfair means, such as the bribery of a clerk." A dissent took the more familiar view that the third persons "were neither the servants nor partners of the plaintiff and owed him no duty not owed by the whole world."74

Tortious acquisition has also been said to exist where a third person uses knowledge though aware that it was revealed by mistake or breach of obligation.75 Direct prying into a possessor's affairs is likewise said to constitute tortious acquisition, as where an outsider rifles a corporation's papers. ${ }^{76}$ Where disclosure is innocently received, and a notice of breach of duty is later forthcoming, the information, if used, is said to have been inequitably retained. In all such cases, liability for inequitable retention begins to run from the time of notice of the wrong. 77

The trade-secret cases make it clear that use of knowledge acquired by independent discovery or analysis of a product does not create liability. 78 In addition information that is freely disclosed need not be held in trust by a recipient: "Thus if one freely gives full information about the state of his accounts to trade associations, credit agencies, or others who request it, the possession, disclosure or use of the same information can hardly cause ... harm."79 Though the categories of tortious acquisition and inequitable reten-

74118 N.Y. at 37, 2 N.E. at 13; See also 2 RESTATEMENT, AGENCY $\S 312$, comment $c$ (1933); Ohio Oil Co. v. Sharp, 135 F.2d 303, 306 (10th Cir. 1943) (third party inducing geophysicist to disclose confidential information resulting from oil company survey held constructive trustee); RESTATEMENT, TORTS $\$ 759$ (1939).

75 Pressed Steel Car Co. v. Standard Steel Car Co., 210 Pa. 464, 60 At1. 4 (1904) (manufacturer held as constructive trustee where railroad receiving secret plans from one of its suppliers revealed them to supplier's competitor to stimulate competition); RESTATEMENT, TORTS $\$ 757(\mathrm{~d})$ : "If the actor has notice that the information is disclosed to him by mistake and that it is another's trade secret, good faith requires that he does not take advantage of the mistake and he is under a duty not to disclose or use the secret."

764 ResTATEMENT, TORTs $\S \S 757$ (a), 759, comment $c$ (1939): "Among the means which are improper are theft, trespass, bribing or otherwise inducing employees or others to reveal the information in breach of duty, fraudulent misrepresentations, threats of harm by unlawful conduct, wire tapping, procuring one's own employees or agents to become employees of the other for purposes of espionage, and so forth." See 2 CALLMANN, UNFAIR COMPETITION AND TraDe Marks 861-63 (2d ed. 1950).

77 Vulcan Detinning Co. v. American Can Co., 75 N.J. Eq. 542, 73 Atl. 603 (Ct. Err. \& App. 1909) (trade secret); Edelstein v. Edelstein, 1 De. G.J. \& S. 199 (1863) (trade-mark infringement). 4 RESTATEMENT, ToRTs $\S 758(\mathrm{~b})$ : "But one who actually pays value in good faith prior to receipt of notice . . . is relieved of the duty. . . . A change of position in good faith may also have this effect." Morrison v. Moat, 9 Hare 241 (1851). See Conmar Products Corp. v. Universal Slide Fastener Co., 172 F.2d 150, 156 (2d Cir. 1949) (L. Hand, J.).

78 Gilbert v. General Motors Corp., 41 F. Supp. 525 (W.D.N.Y. 1951).

79 Restatement, ToRTs $\$ 759$, comment $b$ (1939); Sandlin v. Johnson, 152 F.2d 8, 11 (8th Cir. 1945); McClary v. Hubbard, 97 Vt. 222, 122 Atl. 469 (1923). Compare New York Stock Exchange, Educational Circular 151 (Dec. 15, 1961) which observed that "The Ex: 
tion may be applied with relative ease to securities trading, the trade-secret rule exonerating outsiders from liability for use of freely disclosed information poses more difficult problems in cases where the disclosure is only to inquirers and does not take the form of a public announcement. The extent to which such disclosures should be held to create insider liability should depend on the nature of the information revealed. Thus if investment analysts touring a factory are told of a new piece of equipment or even of an anticipated decline in earnings in the coming year, it would seem unreasonable to compel public disclosure of the information thus obtained, since a rule that would oblige all traders to deal on the basis of a uniform ignorance of corporate affairs would seem unworkable. However, where the information confided to all comers relates to a fundamental corporate change, or a change in policy that directly affects security holders qua security holders, e.g., merger, sale of assets, dividend cuts, or stock conversions, application of trade-secret principles immunizing use of information freely disclosed to inquirers would work considerable unfairness and a more severe rule requiring disclosure to the market would seem warranted.

The appeal of the trade-secret cases as a principle of decision lies in the universality of the rules which they propound. 80 In this respect, of course, they suffer from some of the supposed defects of an "any person" rule, but the requirements of proof of notice of a fiduciary breach will operate to make prosecution difficult if not impossible in cases where relationships are remote. 81

change has received numerous inquiries concerning . . . Cady Roberts. . . It does not seem to the Exchange that the opinion questions the ordinary practices of analysts and brokers seeking and using corporate information of the type company officials would give to anyone having a legitimate interest in the company." The circular warned against the use by brokerage firms of confidential information received from directors, a warning reiterated at a later time. See Wall Street Journal, June 25, 1962, p. 10, col. 2.

so "We do not deem it advisable to lay down any hard and fast rule. . . . Were we to do so, a certain class of gentlemen of the J. Rufus Wallingford type-'they toil not, neither do they spin'-would lie awake nights endeavoring to conceive some devious and shadowy way of evading the law. It is more advisable to deal with each case as it arises." State v. Whiteaker, 188 Ore. 656, 661, 247 Pac. 1072, 1079 (1926). Cf. Stonemets v. Head, 248 Mo. 243, 263, 154 S.W. 108, 114 (1913): "Messieurs, the Fraud-Feasors, would like nothing half so well as for courts to say they would go thus far and no further in its pursuit." The dictum in Allcard v. Skinner, 36 Ch. D. 145, 183 (1887) may now be hyperbole, however: "No court has ever attempted to define fraud." $C f$. Webb v. Rorke, 2 Sch. \& Lef 661,666 (Ir. Ch. 1806) (cited at 3 Loss 1446) where it is said, "If a case arises or fraud . . . to which even no principle already established can be applied, a new principle must be established to meet the fraud ... for the possibility will always exist that human ingenuity in contriving fraud will go beyond any cases which have before occurred."

81 On the nature of "notice," see 1 Restatement, AGENCY $\$ 9$ (1933): "A person has notice of a fact if he or his agent knows the fact, has reason to know it, should know it, or has been given a notification of it." But compare RESTATEMENT, RESTITUTION $\$ 202$, comment $a$, (1937): knowledge may be required to impose a constructive trust where third person disposes of property with notice but without knowledge and acquires other property in exchange. 
Problems of administration have in the past been thought to raise decisive objections to a broad rule. An early draft of section $16(\mathrm{~b})$ of the Exchange Act was revised to eliminate a section which would have provided that:

[A]ny profit made by any person to whom ... unlawful disclosure shall have been made, in respect of any transaction or transactions in such registered security within a period not exceeding six months after such disclosure shall inure to and be recoverable by the issuer unless such person shall have had no reasonable ground to believe that the disclosure was confidential or was made not in the performance of corporate duties. 82

These administrative problems, however, are not likely to arise to as great an extent where a harsh provision of this nature is not at issue. It would have been arbitrary and frequently unjust to require any person receiving information from a director to purge himself of all short-swing profits in that director's corporation even where the profits bore no relationship to the information thus received.83 The possibilities for entrapment would seem considerable under such a rule, since only disclosure need be proven and since an insider could in effect disqualify any person he chose from trading in the stock of his corporation. Different considerations would apply were rule $10 b-5$ to be read to include any person receiving information from insiders. For here, not only disclosure but causation must be shown; the trading and profits must derive from the use of the inside information to be actionable.

Nevertheless, the possibility that receipt of information might in practice be presumed to be the cause of an innocent transaction has aroused anxiety about the possible application of the new rule. 84 This is so even though the decision in the Cady, Roberts case may be read as being predicated on the find-

82 H.R. 7852, 73d Congress, 2d Sess., $\$ 15(b)$.

$83 \mathrm{Mr}$. Wolverton: How are you going to catch anybody?

Mr. Corcoran: Somebody will peach.

Mr. Wolverton: Somebody who was not in.

Mr. Corcoran: Somebody that was not in.

Mr. Corcoran: This information might turn up in tax returns; it might turn up in investigations; it might turn up in lawsuits-when thieves fall out-it might turn up in a lot of ways.

Mr. Corcoran:... Suppose a man is very close to the inside of a corporation and there is circumstantial evidence turning up, for instance, in tax returns, or otherwise, that he did buy stock just before a lift and sold out within six months, and that he was very, very close to a certain officer or director of the company. That might be enough to prove a case against him ... you might from stock records find that somebody on the inside bought just before a dividend was raised.

Stock Exchange Regulation. Hearing on H.R. 7852 Before the House Committee on Interstate and Foreign Commerce, 73d Cong., 2d Sess. 135-73 (1934).

84 Phelps, Hazards of the Stock Market, Atlantic Monthly 81-82 (April 1962). Cf. Windels, supra note 69, at 182 where it is said that: "A very circumspect broker who is also a director may actually be at a disadvantage in the use of information that, although not publicly reported, is generally known, to the great detriment of his customers who look to him for advice in investment matters." 
ing that "the record does not support the contention that Gintel's sales were merely a continuance of his prior schedule of liquidation." 85

It thus seems possible that a more limited rule than that suggested by the trade-secret cases will be adopted. Since the trade-secret cases look only at the knowledge and conduct of the recipient of information, their principle may be limited in two ways: First, by considering the degree of complicity in the outsider's trading of the fiduciary, 86 whether he is an officer, director or controlling shareholder, or second, by considering the relationship of the recipient of information to the trust.

There is ample support at common law for a rule which would impose liability on an insider disclosing information to a third person with knowledge that the recipient would trade in the stock. Benefit to the insider himself is not necessary for the transaction to supply the basis of liability since common-law doctrine extends beyond the agency principles previously discussed. Trust analogies are appropriate as the law lays greater stress on the fiduciary functions of directors.

In some cases at common law, the trustee himself may be charged for profits made by third persons. Thus in the case of Mosser $v$. Darrow, 87 a reorganization trustee allowing an employee of the debtor trusts to deal in trust securities with the estate was charged with the employee's profits for the benefit of the trust, even though the fiduciary did not benefit. The court declared that "that which the trustee had no right to do he had no right to authorize and ... the transactions were as forbidden for the benefit of others as they would have been on behalf of the trustee himself. . . . [It] is a case of a wilful and deliberate setting up of an interest in employees adverse to that of the trust." The absence of detriment to the corporation was deemed irrelevant on well-settled principles which allow a trustee to be surcharged for the proceeds of self-dealing, 88

85 The Commission also made the ambiguous observation that "the practical problem envisaged by respondents in effecting appropriate disclosures in connection with transactions on the Exchange are easily avoided where, as here, all the registered broker-dealer need do is to keep out of the market until the established procedures for public release of the information are carried out instead of hastening to execute transactions in advance of, and in frustration of, the objectives of the release." (Emphasis added.) SEC Securities Exchange Act Release No. 6668, p. 11.

86 The Cady, Roberts result clearly rejects this possible limitation. The Commission took the view that it was "not to be circumscribed by fine distinctions and rigid classifications" (SEC Securities Exchange Act Release No. 6668, p. 6), and inferentially adopted the staff's position that "Gintel's duty is not to be determined by any such fortuitous technicalities. His obligations depend upon what he did in the light of his own knowledge." (Memorandum for Division of Trading and Exchanges, p. 7 ).

87341 U.S. 267, 272 (1951). The trustee surcharged in Mosser was later allowed to recover from the employees on the theory that he was subrogated to the trust's claim against them. Matter of Federal Facilities Realty Trust, 220 F.2d 495 (7th Cir. 1955).

88 An earlier case also arising in the Seventh Circuit was in effect overruled by the Mosser decision. In re Breger Kosher Sausage Co., 129 F.2d 62 (7th Cir. 1942) (trustee not charged for loss to business resulting from loan of funds to employee). But see In re Real Estate 
including his share of commissions ${ }^{89}$ and partnership profits, 90 regardless of whether there was loss to the trust.

Results similar to that in the Mosser case have been reached in bankruptcy cases where the courts have exercised their general equity powers 91 or have acted under statutory provisions proscribing "beneficial interest [s]," direct or indirect, to limit the compensation paid to attorneys and other reorganization officials $^{92}$ where information was disclosed to wives, ${ }^{93}$ distant relatives, ${ }^{94}$ law 95

Mortgage Guaranty Co., 55 F. Supp. 749 (E.D. Pa. 1944) (trustee not liable where beneficiary consents); In re Portex Oil Co., 43 F. Supp. 859 (D. Ore. 1942) (trustee not liable where employee's profit concealed from him); Speight v. Gant, 22 Ch. 727 (1883); Ex parte Belchier, 1 Amb. 217, 27 Eng. Rep. 144 (1794).

"[T]he prohibition is not merely against injuring the estate-it is against profiting out of the position of trust." Mosser v. Darrow, supra note 87, at 273. See also Michoud v. Girod, 4 How. (45 U.S.) 503 (1846); Magruder v. Drury, 235 U.S. 106 (1914); Jackson v. Smith, 254 U.S. 586 (1921); Aberdeen Ry. v. Blaikie Bros., 1 Macq. 461,472 (1954), citing the civil law rule in DigesT 18.1.34.7: "A guardian cannot buy the property of a ward. The same rule extends to similar cases, that is, to those of curators, agents, and those who transact the business of others." 5 CrvIL LAW 11 (Scott trans. 1932) quoting PAUL., ON THE EDICT 33. See also Mackintosh, Roman law of Sale 67 (1892). But compare Digest 27.8.5.23; 3 VOET, COMmENTARY ON THE PANDECTS 265-66 (Gane trans. 1956) (exceptions where judicial sale or consent of co-trustee). For the application of the principle in modern RomanDutch law, see the elaborate discussion in Osry v. Hirsch, Loubser \& Co., 1922 So. Afr. L.R. (C.P.D.) 531-67 (agent liable for profit on resale of ostrich feathers bought of principal at public auction sale).

89 Crites, Inc. v. Prudential Ins. Co., 322 U.S. 408, 414, 418 (1944) (receiver surcharged for commission received on profits from resale of property bought from trust).

90 Albers v. Dickinson, 127 F.2d 957 (8th Cir. 1942) (trustee charged for his share of corporation profits where corporation was operated like partnership); In re Midland United Corp., 64 F. Supp. 399, 417 (D. Del. 1946) (disallowance under $\$ 249$ of Bankruptcy Act where trustee profited through closely held corporation); In re Webster Loose Leaf Filing Co., 252 Fed. 959 (D.N.J. 1918) (trustee charged for wife's share of partnership where wife served as his agent). See also Blau v. Lehman, 288 F.2d 786, 791 (2d Cir. 1961) (insider liable for share of partnership profits under $\S 16(\mathrm{~b})$ of Exchange Act though share renounced); Rattner v. Lehman, 193 F.2d 564 (2d Cir. 1952); Sexton v. Sword Steamship Line, 118 F.2d 708 (2d Cir. 1941) (trustee's share of partnership profits offset against allowance under $\S 77 \mathrm{~B}$ of Bankruptcy Act though share renounced).

91 In addition to their general equity powers to reduce or withhold compensation, courts are accorded additional powers by $\S 249$ of the Bankruptcy Act, which provides that "no compensation or reimbursement shall be allowed to any person acting in a representative or fiduciary capacity, who at any time after assuming to act in such capacity has purchased or sold ... claims or stock, or by whom or for whose account . . . claims or stock have, without the prior consent or subsequent approval of the judge, been acquired or transferred." 52 Stat. 901 (1938), 11 U.S.C. $\S 649$ (1958). The act also empowers courts to surcharge fiduciaries, or limit to cost the value of claims or stock purchased by them.

92 Reorganization committeemen under $\$ 249$ of the Bankruptcy Act are fiduciaries for all share and bond holders, not merely those whom they represent. The act merely codifies a result reached at common law. In re Republic Gas Corp., 14 F. Supp. 703 (S.D.N.Y. 1936); In re Paramount Publix Corp., 12 F. Supp. 823 (S.D.N.Y. 1935); Nichol v. Sensenbrenner, 220 Wis. 165,263 N.W. 650 (1935). It is not clear whether shareholders representing themselves in reorganization proceedings are held under $\S 249$ as fiduciaries to all security holders. See Finn v. Childs Co., 181 F.2d 431, 440-41 (2d Cir. 1950). Compare 18 N.Y.U.L.REV. 399, 475 (1941) with 6 COLLIER, BANKRUPTCY 4594 (14th ed. 1958). Officers 
or brokerage partners, 96 clients, 97 and other persons. Knowledge of the outsider's trading, 98 or advice to him to trade, 99 appears to have been requisite to

and supervisory employees of debtors in possession are not fiduciaries under $\$ 249$, but are still subject to the inherent equity powers we here discuss. In re Nazareth Fairgrounds \& Farmers' Market Inc., 296 F.2d 678 (2d Cir. 1961), cert. granted sub nom. Wolf v. Weinstein, 369 U.S. 837 (1962). Depositary banks appear to be fiduciaries, at least at common law, Matter of Marquette Manor Bldg. Corp., 97 F.2d 733, cert. denied, 305 U.S. 648 (1938), and probably under $\$ 249,6$ Collner, supra, at 4593; contra, Matter of Brown Co., 26 F. Supp. 275 (D. Me. 1941).

93 See Surface Transit, Inc. v. Saxe, Bacon \& O'Shea, 266 F.2d 862 (2d Cir.), cert. denied, 361 U.S. 862 (1959) (disallowances under $\$ 249$ of Bankruptcy Act); SEC v. Dumaine, 218 F.2d 308 (1st Cir. 1954) (disallowance under Public Utility Holding Company Act, Rule U-62); In re Midland United Co., 159 F.2d 340 (3d Cir. 1946) (disallowance under \$ 249 and equity powers); In re Central States Elec. Corp., 112 F. Supp. 281 (E.D. Va.), aff'd, 206 F.2d 70 (4th Cir.), cert. denied sub nom. Henis v. Egan, 346 U.S. 899 (1953); In re Inland Gas Corp., 73 F. Supp. 785, 791 (E.D. Ky. 1947). See also the cases relating to strict trustees, collected in 131 A.L.R. 990 (1940). Contra, Nichols v. SEC, 211 F.2d 412, 416, 418 (2d Cir.) (L. Hand, J.), cert. denied, 348 U.S. 827 (1954) (reversing Long Island Lighting Co., 34 S.E.C. $600,618,620$ (1953)); In re Eastern Gas \& Fuel Associates, 120 F. Supp. 460 (D. Mass. 1953) (no disallowance under $\$ 249$ ).

94 Berner v. Equitable Office Bldg. Corp., 175 F.2d 218 (2d Cir. 1949) (no disallowance under $\$ 249$ but disallowance under equity powers). Compare Long Island Lighting Co., 34 S.E.C. $600,618,620$ (1953) (no disallowance under rule U-62).

95 In re Los Angeles Lumber Prods. Co., 37 F. Supp. 708, 711 (S.D. Cal. 1941) (disallowance under $\$ 249$ where partner traded).

96 In re Mountain States Power Co., 118 F.2d 405, 407 (3d Cir. 1941) (disallowance under equity powers where brokerage house traded, though no profits). Compare In re Midland United Co., 64 F. Supp. 399, 417 (D. Del. 1946) (no disallowance under $\$ 249$ or equity powers where brokerage house executed unsolicited orders).

97 Eastern Gas \& Fuel Associates, 35 S.E.C. 150 (1953) (disallowance under Rule U-62 where attorney's client traded). But compare Silbiger v. Prudence Bonds Corp., 180 F.2d 917, 923 (2d Cir.), cert. denied, 340 U.S. 813 (1950) (no disallowance under $\$ 249$ where attorney's client traded, since no control over his conduct).

98 Compare In re Central States Elec. Corp. 112 F. Supp. 281 (E.D. Va.), motion for leave to appeal denied, 206 F.2d 70 (4th Cir.), cert. denied sub nom. Henis v. Egan, 346 U.S. 899 (1953); Surface Transit, Inc. v. Saxe, Bacon \& O'Shea, 266 F.2d 862 (2d Cir,), cert. denied, 361 U.S. 862 (1959) (disallowances under $\$ 249$ where knowledge of wife's trading); In re Midland United Co., 159 F.2d 340 (3d Cir. 1947) (disallowance under $\$ 249$ and equity powers where knowledge of wife's trading); and SEC v. Dumaine, 218 F.2d 308, 315 (1st Cir. 1954) (disallowance under rule U-62 where knowledge of wife's trading), with SEC v. Dumaine, 218 F.2d 308, 315 (1st Cir. 1954) (dictum); Nichols v. SEC, 211 F.2d 412, 416, 418 (2d Cir.), cert. denied, 348 U.S. 827 (1954) (no disallowance under rule U-62 where no knowledge of wife's trading, though requirement of knowledge could be abrogated by rule); In re Philadelphia \& Reading Iron Co., 61 F. Supp. 120, 128 (E.D. Pa. 1945) (no disallowance under $\$ 249$ where knowledge of wife's trading though requirement of knowledge could be abrogated by statute); Long Island Lighting Co., 34 S.E.C. $600,618,620$ (1953) (no disallowance under rule U-62 where no knowledge of relative's trading). But see In re Eastern Gas \& Fuel Associates, 120 F. Supp. 460 (D. Mass. 1953) (no disallowance under rule U-62 though knowledge of wife's trading); In re Inland Gas Corp., 73 F. Supp. 785, 791 (E.D. Ky. 1947) (disallowance under $\$ 249$ where no knowledge of wife's trading); In re Los Angeles Lumber Prods. Co., 37 F. Supp. 708, 711 (S.D. Cal. 1941) (disallowance under $\$ 249$ where no knowledge of law partner's trading); In re Mountain States Power Co., 35 F. Supp. 307 (D. Del. 1940), modified and aff'd, 118 F.2d 405, 407 (3d Cir. 1941) (disallowance under 
liability in these cases, as was true in the Mosser case. Although statutory provisions demand "beneficial interest," knowledge of a wife's transaction has been treated as equivalent to beneficial interest, so that as to wives, but not other relatives, the statutory and equitable prohibitions are little different. This requirement of knowledge of an outsider's use of information is the chief limitation upon insider liability under the Mosser rule. Following the Mosser decision, corporation directors and fiduciary institutions might have felt concern that they might be held liable, not only for the profits realized by employees acting on the basis of inside information, but for profits obtained by their employees as a result of exchanges of inside information with the employees of other organizations. This concern had little basis. A corporation might fairly be held liable where it knew of transactions in its own stock by its own employees, since in such cases it would ordinarily possess the power to control such transactions. This controlling power would not exist over transactions by employees of other corporations, or to trading in the securities of other corporations. If such transactions were to be reached, a rule that would charge the person making use of inside information was required. A rule that is limited to cases involving complicity on the part of a fiduciary is likely to prove unsatisfactory as a thorough solution to the problems of insider trading, and this limitation was properly rejected by the SEC in Cady, Roberts. 100

Substantial authority exists at common law for a rule that would hold liable outside persons possessing undisclosed information. The majority of such cases proceed on master-servant or agency principles, and charge the outside person for the benefit of the corporation rather than for the benefit of the purchaser or seller of stock. In the case of Brophy v. Cities Service Co., 101 an ordinary employee purchasing stock of a corporation on the open market in anticipation of an increase in its value that would result from the execution

$\$ 249$ where brokerage house traded contrary to partner's instructions to execute orders only); 6 CollIER, BANKRUPTCY 4590 (Supp. 1958) (knowledge of wife's trading should be presumed save where estranged spouse).

99 Berner v. Equitable Office Bldg. Corp., 175 F.2d 218 (2d Cir. 1949).

${ }^{100}$ See note 86 supra. As to another facet of the Mosser rule, see Kaplan, Conflict of Interest in Corporations, UNIVERSITY of CHICAGO LAW SCHOOL, CONFERENCE ON CONFLICT OF INTEREST 34, 47 (Conference Series No. 17, 1961) ("It could also be contended with considerable cogency that a director who knows that another director is purchasing securities on the basis of confidential information may incur liability for failure to prevent such action by his colleague. A trustee has the obligation to prevent a co-trustee from violating their joint trust.... The same result might also be reached by yet another line of reasoning. The Brophy case ... indicates that it is the corporation which has a cause of action against a fiduciary who uses confidential information for his own profit; it might therefore be argued that a corporate asset is involved, and that it is the obligation of each director to protect such corporate asset or be liable for failure to do so.")

10131 Del. Ch. 241, 70 A.2d 5 (1949); Comment, 63 HARV. L. Rev. 1446 (1950). 
of the company's undisclosed plan to buy up its own stock was held liable to the corporation for his profits even though no loss to it was shown.102

In other cases at common law, the courts have indicated a willingness to charge outside persons on an agency theory where an insider made investment decisions on behalf of a relative or where a husband acted as his wife's agent in carrying out a transaction. ${ }^{103}$ In these cases, the insider's information was imputed to his principal, who was held as a trustee. Where an insider is authorized by an associate to procure information, 104 or acts for an associate who ratifies, 105 he may be treated, under ordinary common-law principles, as the associate's agent. The Supreme Court in a dictum in the recent case of Blau v. Lehman ${ }^{106}$ indicated a willingness to apply this agency principle to cases arising under section 16(b) of the Exchange Act, declaring that "Lehman Brothers would be a 'director' of Tidewater if, as petitioner's complaint charged Lehman actually functioned as a director through Thomas, who had been deputized by Lehman to perform a director's function not for himself but for Lehman." But the giving of a "tip" to an outside person, without more, has been held not to be within this principle, 107 nor sufficient to establish the recipient of the tip as a confederate of the insider. In cases arising under section 212 of the Bankruptcy Act, 108 the courts have refused to limit to cost, for the benefit of the corporation, claims purchased by relatives of the insider acting

102 Loss was alleged but not proved. The case nonetheless resembles other cases involving corporate opportunity or use of corporate funds in that there was possible prejudice to the corporation. $C f$. Loft, Inc. v. Guth, 23 Del. Ch. 138, 173, 2 A.2d 225, 241, aff' d, 23 Del. Ch. 255, 5 A.2d 503 (Sup. Ct. 1939); 63 HARV. L. Rev. 1446 (1950).

${ }_{103}$ In re Calton Crescent, Inc., 173 F.2d 944, 951 (2d Cir.) (dictum), aff'd without consideration of the point sub nom. Manufacturers Trust Co. v. Becker, 338 U.S. 304 (1949) (insider investing for relative); In re Frazin \& Oppenheim, 181 Fed. 307, 311 (2d Cir. 1910) (wives charged with husbands' knowledge of fiduciary's status where purchase of property from fiduciary who had unlawfully acquired it from trust estate).

104 RESTATEMENT, AGENCY $\$ 272$ (1933): "[T]he liability of a principal is affected by the knowledge of an agent concerning a matter as to which he acts within his power to bind the principal or upon which it is his duty to give the principal information."

105 RESTATEMENT, AGENCY § 85 (1933): "[R]atification does not result from the affirmance of an act, unless the one acting purports to act on account of another."

106368 U.S. 403, 410 (1962).

107 Manufacturers Trust Co. v. Becker, 338 U.S. 304 (1949). One could argue that directors should be penalized for giving advice based on non-crucial facts that a director might lawfully use in his own investment decisions. "[T]here is a valid reason for allowing a director to buy shares for himself, which does not extend to informing outsiders of the facts on which he is personally free to act; for it is usually of interest to a corporation to have a director increase his stake in it." Berner v. Equitable Office Bldg. Corp., 175 F.2d 218, 221 (2d Cir. 1949) (L. Hand, C. J.) (dictum). But apart from the paradox involved, such a distinction would smack of the early view which regarded inside information as part of the appropriate emolument of directors.

10852 Stat. 895 (1938), 11 U.S.C. $\$ 612$ (1958). 
for their own account where the insider had no interest in the transaction.109 Likewise, an outside businessman, a management consultant, dealing with the corporation was held not liable under this provision of the Bankruptcy Act.110

Agency theories have also been invoked at common law to hold a wife liable for misrepresentations to sellers of stock where her husband acted for her in purchasing stock. ${ }^{111}$ The courts at common law, however, have not held an employee liable to a seller for misrepresentations. ${ }^{112}$ SEC cases arising under rule $10 \mathrm{~b}-5$ shed little light on the liability to buyers or sellers of outside persons doing business with the corporation or extracting information from it. Where a director of a corporation planning to purchase another concern's assets buys stock for his own account without disclosing the acquisition plan, commentators are united in the view that he should be held liable, 113 although the SEC cases are by no means so clear. ${ }^{114} \mathrm{~A}$ broker inducing a corporate employee to transmit information to him was also held liable to a purchaser

109 In re Franklin Bldg. Co., 178 F.2d 805, 807-08 (7th Cir. 1949), cert. denied sub nom. Simonsen v. Emmerling, 339 U.S. 978 (1950); In re Philadelphia \& W. Ry., 64 F. Supp. 738 (E.D. Pa. 1946).

110 In re Philadelphia \& W. Ry., supra note 109.

111 Traerv. Clews, 115 U.S. 528, 534-35 (1885): "In all of the transactions connected with the purchase of the stock Traer acted as the agent of his wife, who knew that her husband was a trustee holding the assets for the stockholders ... and knew their value, and was guided in her purchases by his advice and direction. She knew that Tappan was ignorant of the value of the assets, and she had knowledge of the devices used by her husband ...." In other cases, however, an insider acting as agent for his wife has himself been charged with deceit on the theory that he benefits from the wife's transaction. Broffe v. Horton, 172 F.2d 489 (2d Cir. 1949) (insider liable to fellow insider for failure to disclose identity in purchasing for wife, who exercised independent judgment and had separate brokerage account). The court cited Helvering v. Clifford, 309 U.S. 331, 335 (1939), a tax case involving a short-term trust created by a husband for the benefit of his wife, the husband remaining as trustee. The Broffe case goes beyond both Helvering and the definition of beneficial ownership promulgated by the SEC under $\$ 16(\mathrm{~b})$, which demands an understanding that the husband is to receive "benefits substantially equivalent to those of ownership" or "the power to vest or revest in himself the full legal and equitable title at once, or at some future time, without payment of more than a nominal consideration." SEC Securities Exchange Act Release No. 175 (April 16, 1935), cited in 2 Loss 1101. Cf. the Broffe-like view adopted by the SEC in relation to its own employees: 17 C.F.R. $\$ 200.33$ (Supp. 1962). The Broffe case on its facts is not inconsistent with the bankruptcy cases cited in note 93 supra, since the courts have treated knowledge of a wife's transaction as equivalent to "beneficial interest, direct or indirect," though declining to imply either knowledge or beneficial interest from the existence of the marriage relation itself. $C f$. Saville v. Sweet, 234 App. Div. 236, 254 N.Y. Supp. 768 (1932) (director purchasing as agent for fellow director charged though no beneficial interest, subject to accounting with his principal).

112 Stout v. Cunningham, 33 Idaho 464, 196 Pac. 208 (1921).

1133 Loss 1451-52; Comment, 39 CALIF. L. Rev. 429, 434 (1951); Comment, 59 Yale L.J. 1120, 1134 (1950).

114 See Ward La France Truck Corp., 13 S.E.C. 373 (1943) (purchaser of corporation held for stock purchases between contract and closing). But compare Hughes \& Treat, 22 S.E.C. $623,626 \mathrm{n} .2(1946)$, where the Commission said in a dictum in a case involving a purchaser of a corporation buying stock through a broker: "There is a substantial question whether respondent's purchases were in fact made on behalf of an 'insider' or a person having some 
under rule $10 \mathrm{~b}-5$, but whether the result here was dependent on special duties as a broker is not clear. 115

Few consistent principles emerge from prior cases, save that in all instances where liability has been found, a relationship between insider and outsider existed that went beyond the mere transmission of information. Either the outsider purchased through the insider, or he induced or deputized the insider to procure the information, or he obtained the information as a result of an employment relationship or he traded with the tacit consent of an insider who knew of the transaction and was in a position to control it. Insistence on some such bilateral relationship would eliminate most opportunities for systematic fraud while guarding against possibilities of entrapment and sterilization of contemplated transactions. This, indeed, seems the rule announced in Cady, Roberts, where "the existence of a relationship" was said to be one of the bases of liability. But adoption of more generalized principles of tortious acquisition and inequitable retention are necessary if all transactions are to be reached and if the law is to supply a meaningful guide to conduct. Relationship to the fiduciary is relevant where liability to a trust itself is at issue. Its relevance diminishes where the duty is not to a trust but to investors, and where the law must concern itself with the cultivation of standards of fair dealing meaningful to traders acting in a wide variety of situations.

3. Exchange Transactions. - In the Cady, Roberts decision, the Commission rejected contentions that rule $10 \mathrm{~b}-5$ did not apply to sales of stock, to transactions involving persons not shareholders at the time of purchase, to exchange transactions and to cases where privity with a buyer had not been proven. 116

In holding the rule applicable to sales as well as purchases, the Commission would appear to stand on what is now reasonably firm ground. The Commission could, to be sure, have brought its action under section 17(a) of the Securities Act of 1933, which applies only to sellers.117 It chose not to do so,

fiduciary obligation to ... stockholders." See also Kardon v. National Gypsum Co., 73 F. Supp. 798 (E.D. Pa. 1947). Cf. Mills v. Sarjem Co., 133 F. Supp. 753, 764-65 (D.N.J. 1955), and the English law summarized in 2 Loss $896 \mathrm{n} .159$.

115 Herbert L. Honohan, 13 S.E.C. 754 (1943). Similar suggestions have been made as to Cady, Roberts, though the generality of the Commission's language might seem to preclude such an interpretation. See Comment, 71 YALE L.J. 736, 742-47 (1962), where the broker's "position as part of the policing mechanism of the stock market" is stressed.

116 SEC Securities Exchange Act Release No. 6668, pp. 9-10 (Nov. 8, 1961).

117 Though the wording of $\S 17(a)$ and rule $10 \mathrm{~b}-5$ is similar, there are a number of differences between the two provisions: (1) $\S 17$ (a) applies to activities "in the . . . sale of securities," while rule $10 \mathrm{~b}-5$ refers to activities "in connection with the ... sale." (2) $\$ 17$ (a) makes it unlawful "to obtain money or property" by means of false statements; rule 10b-5 provides it is illegal "to make any such statements." (3) Rule 10b-5 specifically refers to "any facility of any national securities exchange"; $\S 17(a)$ does not. (4) the venue provisions of the Exchange Act are broader than those of the Securities Act. See Loss, SEcuRrTiES REGULATION 1176 (1951). (5) The Exchange Act makes it a misdemeanor to ignore a Commission subpoena; the Securities Act does not. (6) Exchange Act violation is a ground for suspension 
relying on the fact that rule $10 \mathrm{~b}-5$ refers in terms to "the purchase or sale of any security" and on the action of the SEC in striking the limiting words "by a purchaser" from the title to the rule in 1951.118 The availability of an administrative rather than criminal remedy for violation of the rule was probably the decisive consideration in inducing the Commission to proceed under rule 10b-5. However, the implied civil remedy under the rule may also have been a factor, since it is doubtful that section 17(a) supplies the basis for civil liability. 119

The Commission's rejection of attempts to limit application of the rule to cases involving purchasers who were already stockholders ${ }^{120}$ rested primarily on the dictum of Judge Learned Hand in Gratz v. Claughton,121 a case involving insider trading under section 16(b) of the Exchange Act:

[T] he director or officer assumed a fiduciary relation to the buyer by the very sale; for it would be a sorry distinction to allow him to use the advantage of his position to induce the buyer into the position of a beneficiary, although he was forbidden to do so, once the buyer had become one. Certainly this is true, when the buyer knows he is buying of a director or an officer, for he expects to become the seller's cestui que trust. If the buyer does not know, he is entitled to assume that if his seller in fact is already a director or officer, he will remain so after the sale. 122

from membership on an exchange or in the National Association of Securities Dealers; Securities Act violation is not. (7) It is doubtful whether $\$ 17(\mathrm{a})$ of the Securities Act supplies the basis for implied civil liability. See generally Loss, SecurrIIES REgUration 832 (1951). (8) Criminal penalties under rule 10b-5 are limited by \$32(a) of the Exchange Act, which provides that "no person shall be subject to imprisonment [as opposed to fine] ... for the violation of any rule or regulation if he proves that he had no knowledge of such rule or regulation."

118 SEC Securities Exchange Act Release No. 3634, 16 Fed. Reg. 7928 (1951). The rule has been held applicable to sales in Fischman v. Raytheon Mfg. Co., 188 F.2d 783 (2d Cir. 1951); Matheson v. Armbrust, 284 F.2d 670 (9th Cir. 1960), cert. denied, 365 U.S. 870 (1961); Ellis v. Carter, 291 F.2d 270 (9th Cir. 1961). There is a split as to whether the rule is applicable to sales covered by the express civil liability provisions of the 1933 Act for the purposes of private suits. See Dauphin Corp. v. Redwall Corp., 201 F. Supp. 466 (D. Del. 1962) and cases there cited.

119 See 3 Loss 1784-87.

${ }^{120}$ Several commentators have suggested this limitation. See Loss, SecurTtIES REgulATION 833 (1951); Note, 42 VA. L. REv. 537, 546, 563 (1956). One writer carries it even further: "[T] he fiduciary relation arises because of the then ownership by the shareholder of specific shares, and if the transaction is unrelated to those shares-as when the shareholder proposes to buy additional shares from an 'insider' it may be concluded that the shareholder should be in no different position from any other purchaser vis-d-vis the insider." FEUER, PERSONAL LIABILITY OF CORPORATE OfFICERS AND DIRECTORS 174 (1961).

121 The Cady, Roberts opinion noted in passing that "the record contains no evidence to indicate the correctness of the assumption, upon which respondents' contention is apparently based, that none of the persons who purchased the Curtiss-Wright shares sold by Gintel during the interval in question were already shareholders of that company."

122187 F.2d 46, 49 (2d Cir.), cert. denied, 341 U.S. 920 (1951). 
The defendant in Cady, Roberts attempted to distinguish Hand's dictum by arguing that it related to a statute arbitrarily imposing liability on insiders irrespective of the identity of the other party to the transaction, 123 although Hand was addressing himself to the question of the constitutionality of the 16 (b) provision by demonstrating that it was not arbitrary in extending a prohibition to sales to persons not shareholders.

The relevance of Hand's reasoning might have been more convincingly attacked on the ground that it related to the duties of directors, officers, and controlling shareholders-persons who may be assumed to owe a continuing fiduciary duty to the purchaser of stock after he becomes a shareholder. It can hardly be argued that a buyer is entitled to assume that if his non-insider seller possesses inside information, he will continue to possess it and hence owe the buyer a fiduciary duty after the sale when the inside information will have ceased to have value. To the extent that Hand's reasoning stands for the proposition that one owes fiduciary obligations to those whom one induces to become one's cestuis, it is inapplicable to the Cady, Roberts situation.

However, the possessor of inside information can be held to owe fiduciary duties to nonstockholders on more fundamental principles than those invoked by Judge Hand in Gratz v. Claughton. Prior to the passage of the statutory prohibitions in section 249 of the Bankruptcy Act, the common law prohibited reorganization committeemen from purchasing nondeposited bonds even though they were not strictly fiduciaries for shareholders whom they did not represent:

It may be suggested, and in effect is argued, that the committeemen were trustees only for depositors, that their purchases were from nondepositors, and that hence there was no violation of any right of the depositors. ... As I see it, the evil from purchasing nondeposited bonds impinges upon the reason for the rule precisely as would purchasing from a depositor. The prohibition against dealing in bonds of an issue of which a portion ... is being handled by a committee grows out of the requirement that a trustee have no interest, or even temptation, to act adversely to the beneficiaries of his trust. Trafficking in any bonds of the issue would or might beget a desire to buy low or to sell high. The confidence reposed by depositors, as a body, in their trustee, would be abused by such behavior on his part in like fashion and to the same extent irrespective of whether the bonds dealt in were owned by a depositor or a non-depositor. ${ }^{124}$

It is thus doubtful that the distinction contended for existed even at common law, 125 which as to strict trusts at least looked to the nature of the trading

123 Reply Memorandum for Cady, Roberts, p. 7.

124 In re Republic Gas Co., 2 SEC, RePORT ON THE STUDY AND INVESTIGATION OF THE Work, ACtivities, Personnel, and Functions of Protective and Reorganization COMMTTTES 597, 599-600 (S.D.N.Y. 1936) (memorandum of Caffey, J.). See also 2 id. 251-59 (1937); In re Paramount Publix Co., 12 F. Supp. 823, 828 (S.D.N.Y. 1935).

125 The Republic Gas case, supra note 124, arose under the very general provisions of $\S 77 \mathrm{~B}$ of the Bankruptcy Act which provided for compensation "for services rendered." In 
rather than the identity of the opposite party in defining conduct as inappropriate for a fiduciary.

The view that there is no insider liability for transactions over a securities exchange does find support at common law in the well known case of Goodwin v. Agassiz, 126 a case which has been the subject of warm debate since 1933.127 Advocates of the Goodwin rule urge a number of considerations in its favor.

It is argued that in exchange dealings there is no assurance that a disclosure will reach a buyer. ${ }^{128}$ However, this objection has been vitiated by the development of modern communications and the fact that the disclosure will be reflected in the market price. It has also been suggested that where a sale takes place at a market price, the fact that the buyer has knowledge of a probable future rise does not prejudice the seller, who sells because he wishes to sell.129 Whatever the merits of this rationale for insider overreaching as to purchases it is clearly more difficult to justify its use as to insider sales, where the buyer's stock soon depreciates in value.

In addition, it has been maintained that where insiders purchase publicly traded stocks through brokers, "the only practical disclosure would open the field for a broker-speculation." 130 However, where an insider privately purchases a publicly traded stock, it would not be unreasonable to require him to await disclosure to the market. In any event, the Cady, Roberts extension of

Mosser, another reorganization case, the Supreme Court observed that "this was a strict trusteeship, not one of those quasitrusteeships in which self-interest and representative interests are combined." 341 U.S. at 271.

126283 Mass. 358, 186 N.E. 659 (1933). See also Geller v. Transamerica Corp., 53 F. Supp. 625 (D. Del. 1943), aff'd, 151 F.2d 534 (3d Cir. 1945) (dictum). Compare Judge Caffey's observation in the Republic Gas case: "It has been urged that the purchases ... were made in the open market and therefore were warranted. ... [I]t strikes me that the contention is, in effect, identical with that already mentioned, that is, with the contention that a committeeman merits no criticism by buying from a nondepositor." 2 SEC, supra note 124 , at 600 .

127 Compare, e.g., Ballantine, Corporations 216 (1946) ("Dishonest directors should not find absolution from retributive justice by concealing their identity from their victims under the mask of the stock exchange."), with LATTIN, CoRPORATIONS 265-66 (1959) ("Should the officer or director who would be required to disclose his inside information were he dealing personally with the shareholder be required to keep out of the market until the information he has becomes generally known? In a practical world, the answer should be no.").

128 Goodwin v. Agassiz, 283 Mass. 358, 186 N.E. 659 (1933); Walker, Duty of Disclosure by a Director Purchasing Stock from his Stockholders, 32 YALE L.J. 637 (1923).

129 FEUER, op. cit. supra note 120, at 175-76. See also Walker, supra note 128. Contra, Comment, 59 HARV. L. REv. 769, 774 (1946), where the SEC's duty to promote liquid markets is advanced as a justification of itself for extension of the rule.

130 LATTIN, CoRporations 265-66 (1959). See also In re Calton Crescent, Inc., 173 F.2d 944, 949 (2d Cir. 1949) ("As to securities purchasers from over-the-counter traders we should hesitate to lay down the rule that the purchaser from a broker must make disclosure of why he thinks the purchase a desirable investment under penalty of being charged with overreaching if he fails to do so."). 
insider liability to a broker receiving information from insiders overcomes this objection.

The practical impossibility of identifying the shareholders to be reimbursed has also been urged as an objection to liability for exchange transactions. ${ }^{131}$ While this argument may have merit in cases involving civil liability to sellers or purchasers, it is difficult to see its relevance where administrative or criminal penalties are at issue. Where a transaction is forbidden as to all members of a group, the law will usually create a presumption that it is unlawful even though participation of a specific member of the group is not shown, 132

Application of a disclosure requirement to exchange transactions raises the acute question of whether an insider must forego a transaction when he is under a duty to a corporation not to disclose information that might prove valuable to competitors. Although commentators ${ }^{133}$ have suggested that insiders in this situation should be allowed to trade without disclosure, a "minority-rule" court at common law would have required the director to forego a transaction even where a face-to-face transaction necessitating disclosure to only one person was involved.134 While the question was not directly at issue in Cady, Roberts, the Commission by way of dictum took the view that: "If . . . disclosure prior to effecting a purchase or sale would be improper or unrealistic under the circumstances . . . the alternative is to forego the transaction."'135

It has been suggested that the disclosures of information required of companies listed on exchanges ${ }^{136}$ sufficiently narrows the possibility of misuse of

131 Comment, 38 Mich. L. Rev. 137, 150 (1939).

132 Compare the principle that "a bill of particulars should be denied where the information sought is peculiarly within the knowledge of the moving party." Porter v. Shoemaker, 6 F.R.D. 438, 441 (M.D. Pa. 1947).

133 E.g., BerLe 176, 183-84. See also Percival v. Wright, [1902] 2 Ch. 421, 426; Carpenter v. Danforth, 52 Barb. 581, 586 (N.Y. 1868); McManus v. Durant, 168 App. Div. 643, 154 N.Y. Supp. 580,590 (1915). But compare Black v. Simpson, 94 S.C. 312, 77 S.E. 1023, 1025 (1913); Colo. REv. StAT. ANN., ch. 31, $\$ 9.7$ (1953) ('If the indorsement or delivery of a certificate (1) was procured by fraud or duress or (2) was made under such mistake as to make the indorsement or delivery inequitable ... any court may enforce specifically such right to reclaim the possession of the article as to rescind the transfer thereof." [Emphasis added.]).

134 Oliver v. Oliver, 118 Ga. 362, 368, 45 S.E. 232, 234 (1903) (dictum).

135 SEC Securities Exchange Act Release No. 6668, p. 5.

${ }_{136}$ Securities Exchange Act Rule 13(a)(1), Form 10(k) requires submission of an annual report by listed corporations. Rule 13(a)(13), Form $9(\mathrm{k})$ requires semiannual reports of gross sales, operating revenues, net income, extraordinary and special transactions, and charges and credits to earned surplus. Rule 13(a)(11), Form 8(k) requires reporting of specified changes in the capital and control structure of corporations and extraordinary acquisitions and dispositions of assets within ten days after the close of a calendar month in which the actions occur. In addition, the New York Stock Exchange requires immediate reporting of dividend changes and changes in conversion rates, business purchases, redemptions, and cancellations, subscription rights and changes in officers and directors, in addition to information required by the SEC. NEw YoRK STOCK EXCHANGE, COMPANY MANUAL A-91-A-104 (1961). See generally 2 Loss 808-17. 
inside information as to render unnecessary the expansion of rule $10 \mathrm{~b}-5$ to reach the few remaining cases. 137 However, there are a sufficient number of important developments and decisions that are not subject to immediate reporting under either Exchange or SEC rules to justify an expansion of the general fraud provisions. 138 Moreover, when there is a breach of the disclosure rules, the fraud provisions may supply a private remedy that the rules do not; and the rules provide no penalties for trading on the basis of inside information where, as in Cady, Roberts, a failure to report is nonculpable and inadvertent. In any event, the notion that exchange reporting requirements place investors in publicly traded companies in a more favorable position than holders of stock in closely held concerns has been disputed. "The holder of stock in a listed exchange corporation," it has been observed, "is practically never within sight of his company's plants, and not even within astronomical distance of synthesizing intelligently its bookkeeping system."'139 Under this view, reporting requirements merely equalize the position of investors in privately and publicly traded corporations and would not justify a relaxation of fraud provisions as to the latter.

The Commission rejected the defendants' contention that failure to show that the seller of stock was in privity with a specific buyer barred administrative action under the rule. The decision took the position that "the absence of the remedy by a private litigant because of lack of privity does not absolve an insider from responsibility for fraudulent conduct." But the Commission's inferential acceptance of the view that mere lack of privity might bar a civil action in Cady, Roberts is not entirely warranted, though there is rhetoric in the cases to support it.

In the leading case of Joseph v. Farnsworth Corp., 140 the Second Circuit affirmed a decision which observed that "a semblance of privity between vendor and purchaser ... seems to be requisite." The trial court, however, based this assertion on a dictum by Judge Frank in an earlier case141 which

137 FEUER, op. cit. supra note 120, at 175, citing Geller v. Transamerica Corp., 53 F. Supp. 625 (D. Del. 1943).

138 E.g., discoveries of mining resources or major new products, important new contracts, etc. See, e.g., the statement of facts in Donovan v. Taylor, 136 F. Supp. 652 (N.D. Cal. 1955) (suit dismissed on other grounds). For suggestions as to what facts must be disclosed, see Oliver v. Oliver, 118 Ga. 362, 367-71, 45 S.E. 232, 234-35 (1903); Daum \& Phillips, The Implications of Cady, Roberts, 17 Bus. LAw. 939, 953-59 (1962). See also note 47 supra. Cf. United States v. Gilbert, Criminal Indictment No. 62 (S.D.N.Y. June 28, 1962) (indictment under $\$ 17$ (a) for concealment of defalcations).

139 BERLE 180.

14099 F. Supp. 701 (S.D.N.Y. 1951), aff'd, 198 F.2d 883 (2d Cir. 1952). The court of appeals, affirming per curiam, referred to Birnbaum v. Newport Steel Co., 193 F.2d 461 (2d Cir. 1951), where recovery was denied to a person who was neither a purchaser nor a seller.

141 Fischman v. Raytheon Mfg. Co., 188 F.2d 783 (2d Cir. 1951) (recovery allowed to plaintiff purchasing non-listed common stock from underwriter on the basis of misrepresentations in a preferred stock prospectus). 
suggested that a deliberate fraudulent inducement "successful vis-à-vis the . . . shareholders here" was necessary to sustain a cause of action. The requirement in the earlier case was a requirement not of privity in the strict contractual sense but rather of reliance by the buyer. Dissenting in the Farnsworth case, Judge Frank observed that privity of contract was not required at common law to sustain an action in deceit, but that mere reliance on a misrepresentation by "those persons to whom it is made with the intent to cause them to act upon it" 142 was sufficient.

In the Farnsworth case, the defendant sold stock on the basis of misrepresentations during a six month period ending on October 30,1948 , while the plaintiff did not institute purchases until November 12 . Hence it was clear that the plaintiff could not possibly have purchased stock from the defendants. The defendants' misrepresentations were addressed to those persons purchasing stock on the exchange during the six month period that their stock was being sold; they had no interest in addressing misrepresentations to persons subsequently purchasing stock. Thus Judge Frank was compelled to join commentators in conceding that the common-law "rule would support the result in the [Farnsworth] case,"143 and was obliged to attempt, unconvincingly, to show that the common-law rule had been relaxed sufficiently to allow its application in a case where "the defendant had no intent to influence the particular person or class of persons." 144

In Cady, Roberts, unlike Farnsworth, it is possible to view the facts as meeting the strict common-law deceit requirements, at least so far as privity is concerned. The absence of affirmative misrepresentation, however, probably should bar a private action where privity is lacking, despite extreme suggestions to the contrary by some commentators. ${ }^{145}$ All that a private suitor might

142198 F.2d at 885, quoting Restatement, TORTS $\$ 531$ (1938). See Pasley v. Freeman, 3 B. \& P. 367, 100 Eng. Rep. 450 (1789) (recovery allowed against defendant falsely commending third person's credit to plaintiff); Peck v. Gurney, 6 H.L. 377 (1873) (recovery denied to buyer of stock relying on prospectus when stock not bought from issuer), overruling Bedford v. Bagshaw, 4 H. \& N. 537, 157 Eng. Rep. 951 (1859) (recovery allowed buyer relying on false representation made to stock exchange). But compare ResTATEMENT, ToRTS $\$ 536$ (1938) (liability to all persons relying on report required by statute), codified in Securities Exchange Act, $\$ 18(a)$.

1434 StAN. L. Rev. 308, 312 (1952).

144 Judge Frank relied on cases where recovery was allowed to the ultimate taker of negotiable instruments and labelled goods. But in those cases the misrepresentation could be said to have run with the articles sold. See also Davis v. Louisville Trust Co. 181 Fed. 10 (6th Cir. 1910) (recovery allowed where reliance upon false statements made to mercantile agency). Compare Ultramares Corp. v. Touche, 255 N.Y. 170, 174 N.E. 441, 447 (1931) ("A representation, even though knowingly false, does not constitute ground for an action of deceit unless made with the intent to be communicated to the person or class of persons who act upon it to their prejudice.").

145 One commentator has suggested that the ambit of liability for nondisclosure should be wider than that for misrepresentation. Keeton, Fraud-Concealment and Nondisclosure, 15 Texas L. REv. 1, 38-39 (1936): Recovery for nondisclosure should be allowed "not because ... conduct ... a amounting to an implied representation was relied on ... but be- 
need to show, were misrepresentations present, was that he had purchased Curtiss-Wright stock during the same period that Gintel was selling. While the purchaser might not be in privity with Gintel, he would still be among the class composed of "those persons to whom [a misrepresentation] is made with the intent to cause them to act upon it,"146 i.e., the class of persons trading on the Exchange during the definable period in which the stock was sold. Indeed, the court in Farnsworth allowed leave to plead anew, and "express[ed] no opinion upon the sufficiency of a complaint alleging reliance by plaintiffs on [a] November 12, 1948 statement" or alleging later sales by the individual defendants. ${ }^{147}$

There is nothing in the other decided cases where the privity question has arisen that is inconsistent with this view. Complaints have been dismissed where there was a failure to allege that a person making misrepresentations had sold stock at all, and where the stipulated facts made it clear that the stock was sold to clients of a brokerage house with which the plaintiff had not dealt. 148 In neither of these cases was there any possibility that the plaintiff could have bought the shares sold by the defendant.

On the other hand, where the defendant insiders pooled their stock and sold it to the general public through a broker, a buyer was allowed to maintain an action even though he could not show that he had purchased stock from any particular defendant. ${ }^{149}$ A separate count of the complaint alleging violation of section 12(2) of the Securities Act of 1933 also survived demurrer, even though the more stringent language of that section gives a cause of action against a seller only "to the person purchasing such security from him."150 Similarly, a suit against an issuer of bonds by a remote purchaser was allowed

cause entering the contract coupled with ... silence as to the defects of the subject matter of the bargain does not constitute fair conduct. On this basis, reliance is as foreign to this inquiry as it is foreign to the plaintiff's cause of action produced by negligence. . . . [T] he fact which makes most misrepresentations false is not of a character which requires a disclosure; consequently reliance (on a misrepresentation) must necessarily be shown." But this essentially misconceives the nature of liability for negligence, which is not unbounded, but limited by foreseeability of damage. Where injury to property rather than the person is at issue, and words rather than physical force the instrumentality involved, foreseeability does not extend far beyond the parties to a contract, as the Ultramares case, supra note 144, makes clear. There seems no good reason why the liability of a stocktrader for breach of a statutory duty of disclosure should be broader than the liability of an accountant for breach of a professional duty of due care. Of course, where doctrines of constructive fraud have broadened liability for breach of the latter duty, liability for breach of the former may be broadened also. Compare State Street Trust Co. v. Ernst, 278 N.Y. 104, 15 N.E.2d 416 (1938), with the cases involving half-truths and brokers' opinions cited at notes 25 and 44 supra. But nondisclosure without more should not impose a duty where privity is lacking.

146 Restatement, TORTS $\$ 231$ (1938).

14799 F. Supp. at 706, 707.

148 Holmberg v. Williamson, 135 F. Supp. 493 (S.D.N.Y. 1955); Donovan v. Taylor, 136 F. Supp. 552,553 (N.D. Cal. 1955).

149 Buchholtz v. Renard, 188 F. Supp. 888 (S.D.N.Y. 1960).

15048 Stat. 84 (1933) 15 U.S.C. $\$ 771(2)$ (1958). 
even though no privity existed.151 Thus courts have sanctioned actions under the rule where it was either certain or possible that the plaintiff had purchased stock sold by the defendant. If such persons, whether viewed as possible buyers or as members of a class to which misrepresentations are addressed, are allowed to sue, the defendant becomes potentially liable for claims on a greater number of shares of stock than those sold by him. Proof of damage, rather than privity would then by necessity become the limiting principle. But if rule $10 \mathrm{~b}-5$ is viewed as creating a civil remedy for fraud or deceit, this result is no different from that which normally obtains in connection with tort actions, 152 and is no more objectionable than the result of the Ultramares case.153 Different questions arise when the purchaser's suit is for rescission under section 29(b) of the Exchange Act; in such a case, privity, of course, would be required. 154

4. Conflicting fiduciary duties.-The decision in Cady, Roberts flatly rejected the assertion that a broker's fiduciary duty to his discretionary accounts can justify nondisclosure and declared that "this relationship could not justify any actions . . . contrary to law."155 Though this holding would seem to be the least contestible aspect of the Cady, Roberts decision, it has aroused wider discussion in the public press than any other portion of it. ${ }^{156}$

151 Texas Continental Life Ins. Co. v. Bankers' Bond Co., 187 F. Supp. 14 (W.D. Ky. 1960), aff'd sub nom. Texas Continental Life Ins. Co. v. Dunne, CCH FED. SEC. LAw ReP. $\$ 91,170$ (6th Cir. 1962) ("It was not necessary that there be privity between plaintiff and the defendants in the sale of the bonds. ... . If this were not so the issuers and brokers could easily evade liability under the law because it is well known that the original purchasers of the securities do not always retain them as permanent investments and that the public trades in securities."). The case was remanded for determination of a factual issue.

152 Cf. Pasley v. Freeman, 3 Term R. 51, 100 Eng. Rep. 450, 454 (1789) ("If A by fraud and deceit cheats $B$ out of $£ 1,000$, it makes no difference to $B$ whether $A$, or any other person pockets that $£ 1,000$. He has lost his money, and if he can fix fraud upon $A$, reason seems to say that he has a right to seek satisfaction against him.").

153255 N.Y. 170, 174 N.E. 441 (1931).

15415 U.S.C. $\$ 78 \mathrm{cc}(\mathrm{b})$ (1958). See Shulman, Civil Liabilities and the Securities Act, 43 YALE L.J. 227, 229-33 (1933). It has been suggested, however, that a third-party beneficiary relationship might suffice. See Brouk v. Managed Funds Inc., 286 F.2d 901, 908 (8th Cir. 1961) (dictum).

155 SEC Securities Exchange Act Release No. 6668, p. 11. In support of a contrary position, the respondent relied upon the cases of Van Alstyne, Noel \& Co., 33 S.E.C. 311 (1952) and Johnson v. Winslow, 155 Misc. 170, 279 N.Y. Supp. 147 (Sup. Ct. 1935). But those cases established that a broker owes a duty of full disclosure to those with whom he trades, not that he owes his trust accounts a duty not to make disclosure to those with whom he trades. The respondent also saw fit to cite Knapp v. Penfield, 143 Misc. 132, 256 N.Y. Supp. 41 (Sup. Ct. 1932) (backer of musical comedy, "an elderly lady over eighty years of age," held privileged to induce the breach of an employment contract with Miss America of 1923, who "was not equal to singing the theme song"). Memorandum for Respondent Gintel, p. 14.

156 See, e.g., Phelps, "The Hazards of the Stock Market," Atlantic Monthly, April, 1962; Sibley, "Fair Play on Wall Street: Some Dilemmas of a Dealer in Stocks," New Republic, March 12, 1962; Business Week, Nov. 14, 1961, p. 29. For other comments in the public press, see Cormiter, Wall Street's SHADY SiDE 115-19 (1962); Furler, The MoNey ChaNgers 120-22 (1962); Wall Street Journal, Nov. 14, 1961, p. 2, col. 1; Sept. 19, 1962, p. 1, col. 6 . 
It would seem clear that a discussion of conflicting obligations is out of place in Cady, Roberts. A trust position is not a license to assault the universe. ${ }^{157}$ It does not convert the trustee into a twentieth-century Robin Hood, empowered to exact plunder from others on behalf of worthy causes. 158 The fact that a broker can realize personal gain by demonstrating his "market prowess" on behalf of trust accounts adds to, but does not alter, the principle, which should apply equally to personal transactions, transactions on behalf of trust accounts, investment advice and transactions involving charitable organizations. Some guidance as to the potentiality for abuse of transactions in each of these categories may be derived from a review of SEC experience under Public Utility Holding Company Act Rule U-62,159 which imposes an absolute ban of the 16(b)-type on all such transactions by reorganization committeemen subject to the act. The rule also prohibits the execution of unsolicited orders by brokerage firms in which committeemen have an interest. The ban on execution of unsolicited orders has been relaxed with some frequency, 160 while the ban on investment advice has been relaxed, subject to

157 See CAFN, THE MORAI Decision 149-53 (1955): "Loyalty then exacts more than the fulfillment of responsibility; it requires the manager to identify himself with his coadventurers by renouncing some of his own selfish interests and some of his usual economic freedom. ... [F] initeness in the duty of loyalty serves to maintain its moral worth. S- owed an allegiance to $\mathrm{M}-$, an allegiance which was all the stronger by virtue of being bound on every side. One of the firm limits on that allegiance was that $M-$ could not have required $\mathrm{S}$ — account. S- as trustee had neither the duty nor the right to steal in order to benefit his trust. ... It is not a breach of faith to abstain from acts of oppression; on the contrary, the trustee's promise to avoid using the trust fund to oppress others should be considered one of the fundamental and unalterable terms of every trust." See Meinhard v. Salmon, 249 N.Y. 458, 164 N.E. 545 (1928).

158 Compare Sibley, supra note 156: "University trustees are often good businessmen. But is the corporation director free to disclose information to his fellow trustees which may be of benefit to the University? The conflict here is sharpened because of the nature of the institution which he serves. Its charitable purpose might be thought to make permissible some activities barred to individuals operating solely for personal gains."

15917 C.F.R. 250.62; 17 C.F.R. 250.100.

160 Edward Hopkinson, Jr., 13 S.E.C. 404, 407-10 (1943) ("Inasmuch as the routine execution of an unsolicited order to buy or sell allows for no exercise of discretion which might be influenced by inside information, considerations of expediency . . . outweigh consideration of protection."); Godfrey B. Simonds, 16 S.E.C. 116 (1944); William C. Langley, SEC Holding Company Act Release No. 8816 (1949); Benjamin F. Gray, SEC Holding Company Act Release No. 9687 (1950); Percival E. Jackson, SEC Holding Company Act Release No. 13,812 (1958). Accord, Comment, 62 Colum. L. Rev. 735,741 (1962); Daum \& Phillips, The Implications of Cady, Roberts, 17 Bus. LAw. 939, 951-52 (1962). But compare Comment, 71 YALE L.J. 736, 746 (1962). ("It may be argued that a broker in such a case has acted merely as an agent, and that his inside information should not be considered since it was not conveyed .... . But non-public information possessed by a broker will in all likelihood play some role, albeit indiscernible, in any transaction to which he is an advisor. The most satisfactory solution ... would be to place upon the broker a duty to disclose . . .."). Execution of unsolicited orders by a brokerage house has been held to disqualify a broker from compensation under $\S 249$ of the Bankruptcy Act. In re Midland United Co., 64 F. Supp. 399, 417 (D. Del. 1946). But compare the ambiguous opinion in In re Mountain States 
supervision, as to fiduciary accounts. ${ }^{161}$ No significant relaxation on the ban on trading for discretionary accounts has taken place. 162

The view has been expressed that the Cady, Roberts decision may result in a large number of withdrawals by brokerage partners and trustees from corporate directorships.163 This assumption is based on the fear that innocent transactions that coincide with important new corporate decisions may give rise to a presumption that inside information had been improperly used. However, the recent case of Blau v. Lehman ${ }^{164}$ suggests that courts will be unwilling

Power Co., 35 F. Supp. 307, 311 (D. Del. 1940), aff'd, 118 F.2d 405 (3d Cir. 1941). The Cady, Roberts opinion is also ambiguous on this point, observing that the "prohibition extends not only over his own account but to selling for discretionary accounts and soliciting and executing other orders." SEC Securities Exchange Act Release No. 6668, at p. 7. If execution of unsolicited orders is exempt under the rule, merely making a market in a security would not, absent a consistent pattern of profitable changes in inventory, result in liability. But the risk of liability is such as to make participation in making a market undesirable, and withdrawal of directors' firms as specialists or dealers would seem necessary as long as broker-dealer functions remain unsegregated. $C f$. New York Stock Exchange, Educational Release 151 (1961) ("Usually the responsibilities of a director are clear-cut and recognized by a member organization. What may not be as evident is that more than ordinary diligence is required when the director relationship is combined with options to acquire the security while dominant participation in the market by the firm may enhance the value of such options."). See also Kennedy, Problems of Securities Underwriters and Dealers (mimeo 1962) (address before the Section on Corporation, Business, and Banking Law of the American Bar Association), reprinted in 18 Bus. LAw. 71 (1962).

161 Edward Hopkinson, Jr., 13 S.E.C. 404 (1943); Godfrey B. Simonds, 16 S.E.C. 116 (1944); International Hydro-Electric System, SEC Public Utility Holding Company Act Releases Nos. 12,379, 12,412 (1954). But compare Thomas J. Walsh, 18 S.E.C. 218 (1945); Lee S. Buckingham, 10 S.E.C. 1063 (1942).

162 But see William C. Langley, SEC Holding Company Act Release No. 8077 (1948) (life insurance company allowed to trade where necessary to comply with Massachusetts law providing that assets of insurance company must be at disposal of its board of directors); Edward Hopkinson, Jr., 13 S.E.C. 404 (1943) (exception as to trading in preferred stock and bonds of subsidiary of reorganized corporation where stock and bonds were selling at or near par, and fluctuation was unlikely).

163 See Phelps, "Hazards of the Stock Market," Atlantic Monthly, April 1962, pp. 80-81. This forecast has received confirmation. "The familiarity with a company's affairs which is derived from the financial advisor or director relationship, in turn leads to investment in the company's securities and recommendations to the customers of a firm .... The subjection of the broker to vague and ill-defined risks because of the relationship will result in and has already caused many competent persons to refuse to accept directorships." Daum \& Phillips, The Implications of Cady, Roberts, 17 Bus. LAw. 939, 959 (1962). See also Windels, Some S.E.C. Problems and Techniques, 8 N.Y.L.J. 169, 183 (1962) ("[S]ome mutual funds will not permit persons associated with them to serve as directors of the issuers of their portfolio securities. Many an investment-banking house is now adopting this practice even though it has underwritten a distribution of securities of the issuer."). See also Wall Street Journal, Sept. 19, 1962, p. 1, col. 6.

164368 U.S. 403 (1962), 50 CALIF. L. REv. 500 (1962). Before deciding questions of law, the Supreme Court affirmed, as "not clearly erroneous," the trial court's finding that the defendant partnership's profits were made on its own initiative, independent of any advice given it by a member-director. This conclusion was reached on a record that contained testimony that "respondent Thomas had succeeded Hertz, another Lehman partner, on the 
to indulge in such automatic presumptions, absent added proof. It must also be remembered that conclusive proof of causation was present in Cady, Roberts. It may thus be possible for brokers to remain on corporate boards while trading in the stock of such corporations. Caution, of course, is warranted where they do so. The Cady, Roberts decision is at the very least a warning to directors to abandon the remnants of the notion that they serve as representatives of special interests rather than as fiduciaries for shareholders as a whole.

A more cautious, but probably unnecessary, course of action would demand that brokers and trustees refrain from making investments in corporations in which their associates serve as directors. It has been observed that this limitation would constitute a betrayal of trust responsibilities, 165 even though only a very severe definition of trust responsibilities would demand that a trustee be free to make any lawful investment on behalf of his beneficiary. $166 \mathrm{In}$ fact, no trustee is ever thus free, since he is limited, at least to a small extent by probibitions against self-dealing. Forbidding a trust company or brokerage house to make investments in the handful of corporations on whose boards it may be represented will not ordinarily so narrow the possible range of investment choices as to constitute an abdication of a trustee's obligation to make the best possible investment for his cestuis. The customary explanation advanced for the presence of brokerage partners on corporate boards derives from the superior financial advice they may bring to the management of fledgling corporations. Representation on a number of smaller corporate boards is not inconsistent with the discharge of trust responsibilities, and corporations so large and well established as to be almost obligatory investments for trust monies are ordinarily less dependent on the capital market and have adequate financial management of their own. Express trustees, and directors of mutual and pension funds and insurance companies are presented with similar problems by the Cady, Roberts decision; but to the extent that the investments of such funds tend to be of a stable character, there is less risk that trustees will run afoul of prohibitions against insider trading whatever course they may adopt.

5. Implied Civil Liability.-In its decision in Cady, Roberts, the Commission for the first time took note of the fact that because of the implication of

board ... that Hertz had 'joined Tidewater Company thinking it was going to be in the interests of Lehman Brothers'; and that he had suggested Thomas as his successor partly because it was in the interest of Lehman." 368 U.S. at 406. The trading partner had testified that Thomas "spoke very highly of the management and prospects of the Tide Water Oil Company." Blau v. Lehman, 286 F.2d 786, 795 (1960).

165 Phelps, supra note 163.

166 There is no such general principle in the law of trusts. "Any legal entity capable of taking the title to the trust property may be a trustee of it." BOGERT, TrusTs 112 (3d ed. 1952). 
civil liability for statutory violations, "the securities acts may be said to have generated a wholly new and far-reaching body of federal corporation law."'167 The chairman of the Commission has subsequently gone further: "Counsel must be aware of the rights and duties created by this jurisprudence and must appreciate its applicability to a two-man corporation as well as to A.T.\&.T. In all probability, this federal influence will expand rather than contract."168

The bases of this liability are three-fold. First, recourse may be had to the common-law doctrine implying tort liability from violation of a criminal statute. Second, the void contract provision of section 29(b) of the Exchange Act may be held to create a civil right of action under common-law principles. Third, support for implied liability may be drawn from certain jurisdictional provisions contained in section 27 of the act. Examination of each of these approaches is necessary if the vitality of the implied liability doctrine is to be appraised.

Civil tort liability has been implied in a large number of cases arising under both rule 10b-5169 and other provisions of the Securities Acts. 170 The courts have generally proved willing to view investors as members of a class protected by the criminal provisions of securities legislation. However, decisions construing state laws imposing criminal liabilities upon corporate directors are by no means as uniform, 171 and the Second Circuit has twice suggested that it might decline to imply civil liability for violation of the SEC proxy rules. ${ }^{172}$ The application of the doctrine to insider-trading cases should not be taken for granted, since the question has not yet been passed upon by the Supreme

167 SEC Securities Exchange Act Release No. 6668, p. 4. See also McClure v. Borne Chemical Co., 292 F.2d 824, 834 (3d Cir. 1961).

168 Cary, Book Review, 75 HARv. L. REv. 857, 858-59 (1962).

169 E.g., Hooper v. Mountain States Securities Corp. 282 F.2d 195 (5th Cir. 1960); Errion v. Connell, 236 F.2d 447 (9th Cir. 1956); Speed v. Transamerica Corp., 235 F.2d 369 (3d Cir. 1956); Beury v. Beury, 222 F.2d 464 (4th Cir. 1955) (dictum); Fratt v. Robinson, 203 F.2d 627 (9th Cir. 1953); Fishman v. Raytheon Mfg. Co., 188 F.2d 783 (2d Cir. 1951); 3 Loss 1963.

170 The cases are collected in North, "Implied Civil Liability Cases Under the Federal Securities Laws," Corporate Practice Commentator, May 1962, p. 1.

171 Compare Drees v. Minnesota Petroleum Co., 189 Minn. 608, 250 N.W. 563 (1933); Shepard v. City Co. of N.Y., 24 F. Supp. 682 (D. Minn. 1938), appeal dismissed, 106 F.2d 994 (8th Cir. 1939) (tort liability for failure to register stock implied), with Barth v. Klicpera, 248 Mich. 460, 227 N.W. 757 (1929) (tort liability for failure to register stock not implied). Cf. Hayman v. Morris, 36 N.Y.S.2d 756, 766 (Sup. Ct. 1942) (no implied liability in derivative action under penal law forbidding corporation from purchasing own stock out of capital); Steckler v. Pennroad Corp., 136 F.2d 197, 202 (3d Cir. 1943) (no implied liability in derivative action under penal law forbidding holding corporation from owning more than specified percentage of railroad stock). See also notes 230, 231 infra.

172 Howard v. Furst, 238 F.2d 790, 793 (2d Cir.), cert. denied, 353 U.S. 937 (1956) (dictum), 70 HARv. L. REv. 1493 (1957); Subin v. Goldsmith, 224 F.2d 753, 765-66, 774 (2d Cir.), cert. denied, 350 U.S. 883 (1955) (dictum). But see Dann v. Studebaker-Packard Corp., 288 F.2d 201 (6th Cir. 1961). 
Court with reference to any of the securities legislation. 173 The conflicting approaches that may be taken to the problem are illustrated by the recent split between the Second and Eighth Circuits in relation to implied civil liability under the Investment Company Act. Whether civil liabilities under this legislation "are implied unless the legislature evidences a contrary intention"174 or whether "the courts will imply a liability only to implement a manifest intent"175 is a question which, contrary to recent hopes, the Supreme Court will not reach in the immediate future. 176

It seems clear that the Eighth Circuit's dictum goes too far, and that manifest legislative intent has little to do with the implication of liability. In the United States, unlike Great Britain and Canada,177 cases in this area tend to turn not on manifest legislative intention but on the character of the interest to be protected. This is the thrust of the Restatement rule,178 and American

173 Certiorari has been denied in three cases involving an implication of civil liability under rule 10b-5. Matheson v. Armbrust, 284 F.2d 670 (9th Cir. 1960), cert. denied, 365 U.S. 870 (1961); Hooper v. Mountain States Securities Corp., 282 F.2d 195 (5th Cir. 1960), cert. denied, 365 U.S. 814 (1961); McClure v. Borne Chemical Co., 292 F.2d 824 (3d Cir.), cert. denied, 368 U.S. 939 (1961).

174 Brown v. Büllock, 194 F. Supp. 207, 224 (S.D.N.Y.), aff'd, 294 F.2d 415 (2d Cir. 1961). Accord, Panama R.R. v. Rock, 266 U.S. 209, 216 (1924) (Holmes, J., dissenting) ("iS\}tatutes even when in terms covering only particular cases may imply a policy different from that of the common law ...."); Thayer, Public Wrong and Private Action, 27 HARv. L. Rev. 317, 320 (1914).

175 Brouk v. Managed Funds, Inc., 286 F.2d 901 (8th Cir. 1961), vacated as moot, 369 U.S. 424 (1962). Accord, United States v. Constantine, 296 U.S. 287, 298-99 (1935) (Cardozo, J., dissenting) ("The judgment of the court rests upon the ruling that another purpose, not professed, may be read beneath the surface.... Thus the process of psychoanalysis has spread to unaccustomed fields."); Lowndes, Civil Liability Created by Criminal Legislation, 16 MINN. L. REv. 361 (1932).

176 Brouk v. Managed Funds, Inc., supra note 175.

177 The early doctrine of Couch v. Steel, 3 E. \& B. 402, 410, 118 Eng. Rep. 1193, 1196 (Q.B. 1854) held that "in every case where a statute enacts, or prohibits a thing for the benefit of a person, he shall have a remedy ... for recompense of a wrong done him contrary to said law." But this view has been greatly qualified by English courts. See Atkinson v. Newcastle \& Gateshead Waterworks Co., 2 Ex. D. 441, 448 (1877) (liability "depend[s] on the purview of the legislature in the particular statute, and the language which they have there employed ...."); Phillips v. Britannia Hygienic Laundry Co., [1923] 2 K.B. 832, $840-41$ (liability "depends on the intention of the act"); Glanville Williams, The Effect of Penal Legislation in the Law of Tort, 23 MoD. L. REv. 233 (1960). See also Direct Lumber Co. v. Western Plywood Co., 32 D.L.R.2d 227, aff'd, 39 W.W.R. 43 (1962) (declining to imply private right of action under Alberta price discrimination law). In general, British law implies civil liability only where there is some statutory indication that liability is intended, or where penal legislation defines a duty of care existing at common law. Industrial legislation, however, is an exception to this rule. See also Monk v. Warbey, [1935] 1 K.B. 75. But liability is readily implied under civil law. See Newman, Breach of Statute as the Basis of Responsibility in the Civil Law, 27 CAN. BAR Rev. 782 (1949). For an American approach strikingly at variance with the British, see Morris, Role of Criminal Statutes in Negligence Actions, 49 ColUM. L. REv. 21, 48 (1949).

178 RESTATEMENT, TORTS $\$ 286$ (1938): "The violation of a legislative enactment by doing a prohibited act or by failing to do a required act, makes the actor liable for an invasion of an 
courts have proven generally willing to imply liability on this basis under both statutes 179 and administrative regulations. 180

The courts have made a number of attempts to develop a semblance of consistent doctrine in the field. A rule that would decline to imply civil liability for torts not recognized at common law has gained little favor. ${ }^{181}$ Sometimes stress has been placed on the severity of the criminal penalty and the size of the resulting civil liability. ${ }^{182}$ Distinctions between misfeasance and nonfeasance have been drawn, 183 although these have not been satisfactory to those viewing civil liability as a means of controlling conduct rather than assuring redress. 184 Finally, it has been suggested that absolute liability statutes should not supply the basis for tort actions since the requisite fault is not present, ${ }^{185}$ even though it is not explained why courts are more shocked by absence of fault than by absence of criminal intent. The attempted distinction here seems to rest on revulsion against the "Darkness at Noon" quality of the criminal statutes themselves.

The Restatement rule, with its stress on injury to protected interests rather

interest of another if: (a) the intent of the enactment is exclusively or in part to protect an interest of the other as an individual; and (b) the interest invaded is one which the enactment is intended to protect; and (c) where the enactment is intended to protect an interest from a particular hazard, the invasion of the interest results from that hazard; and (d) the violation is a legal cause of the invasion."

179 Tunstall v. Brotherhood of Locomotive Firemen, 323 U.S. 210 (1944) (provision of Railway Labor Act barring racial discrimination by labor unions); Fitzgerald v. Pan American World Airways, 229 F.2d 499 (2d Cir. 1956) (statute barring discrimination by air carriers); and Reitmeister v. Reitmeister, 162 F.2d 691 (2d Cir. 1947) (wiretapping provisions of Communications Act of 1934), are among the more notable cases. Numerous cases are collected in 3 Sutherland, StatuTORY Construction $\$ 5403$ (1943). Failure to obtain a license, however, is usually held not to supply a basis for civil liability, a rule that perhaps may be relevant in connection with violation of the registration provisions of the 1933 act. See Browne v. Shane, 242 N.Y. 176, 151 N.E. 197 (1926) (physician's license); 3 SutherLAND, StatuTORY CoNSTRuCtion 25 n.5 (1943). But compare Whipple v. Grandchamp, 261 Mass. 40, 158 N.E. 270 (1927). See generally 2 Loss 941 ; Note, 48 ColUM. L. REV. 456 (1948).

180 See 3 SUTHERLAND, op. cit. supra note 179, at $24 \mathrm{n} .3$.

181 Mairs v. Baltimore \& O.R.R., 73 App. Div. 265, 76 N.Y. Supp. 838 (1902), aff'd, 175 N.Y. 409, 67 N.E. 901 (1903); Mack v. Wright, 180 Pa. 472, 36 Atl. 913 (1897); Evers v. Davis, 86 N.J.L. 196, 90 Atl. 677 (1914); Williams, supra note 177, at 256-57 support the distinction. Contra, Restatement, TORTS $\$ 286$ (1938); Abounader v. Strohmeyer \& Arpe Co., 243 N.Y. 458, 154 N.E. 309 (1926); Note, 48 Colum. L. Rev. 456 (1948).

1822 COOLEY, TORTS 1400 (3d ed. 1906); 2 HARPER \& JAMES, TORTS 999 (1956); WINFIELD, CASES ON TORT 174 (2d ed. 1943).

183 Thayer, supra note 174; Kirby v. Boyleston Market Ass'n, 80 Mass. (14 Gray) 249 (1859); Flynn v. Canton Co., 40 Md. 312, 326 (1874); Heeney v. Sprague, 11 R.I. 456 (1877); Note, 13 CaIIf. L. REv. 428 (1925).

184 Morris, supra note 177 , at 468. See also Restatement, ToRTs $\$ 286$ (1938).

185 Note, 48 Colum. L. Rev. 456, 462 (1948); Morris, supra note 177, at 458-59, 472-73 Cf. Taber v. Smith, 26 S.W.2d 722 (Tex. Civ. App. 1930); Burlie v. Stephens, 113 Wash. 182 193 Pac. 684 (1920). 
than fault, has been criticized by the supporters of the view that civil liability primarily serves an in terrorem function. ${ }^{186}$ But this stress on defined duties rather than absolute prohibitions seems central to the law of torts and is the chief limitation placed on the implication of liability. 187 The private attorneys general created by provisions like 16 (b) have few precursors at common law. In the ordinary $10 \mathrm{~b}-5$ case, the contemplated causation would seem clear enough. Demands for a clearer showing of a connection between criminal invasion of a protected interest and civil injury may be made when derivative actions under the rule are at issue or when efforts are made to imply civil liability under provisions like the SEC proxy rules.

The imposition of liability for nondisclosures under the rule should not pose problems unless the courts revert to the earlier misfeasance-nonfeasance distinction. The relevance of that distinction would seem limited to actions for negligence, not actions where fraud, even if constructive, is at issue. Liability for nondisclosure when the statutory duty is known differs from vicarious liability, which still retains its capacity to disturb the courts as the recent Brouk case indicates. 188 The criminal penalties for Exchange Act violations are sufficiently large to sustain implied liability on a tort theory ${ }^{189}$ should the relative severity of penalties be considered significant.

The provision of section 29(b) of the Exchange Act making void "every contract made in violation of any provision" of the act has been held to give a

186 Morris, supra note 177, at 470-77: "If the criminal court may punish any act which has a vicious tendency even though it happens to cause no loss, it may not be amiss for the civil court to punish the same act even though the injury which coincidentally occurs is not of the type which the legislature sought to prevent." Id. at 475. Cf. Grey's Ex'r v. Mobile Trade Co., 55 Ala. 387 (1876). The orthodox rule is that of Gorris v. Scott, L.R. 9 Ex. 125 (1874).

187 Cf. Morris, The Relation of Criminal Statutes and Tort Liability, 46 HARV. L. REv. 453, 476 (1932): "In this paper there is no attempt to indicate the basis of limitation of liability ... but regardless of what the limiting principle should be, the rule of Gorris $v$. Scott is ill-advised."

188 Brouk v. Managed Funds, Inc., 286 F.2d 901 (8th Cir. 1961). The court accepted the contention that "there is a fundamental and critical distinction to be drawn between a case where a director is an actor and joint tort feasor in violating a statute and a case where the asserted liability is predicated upon vicarious liability for allegedly causing the corporation he serves to violate the statute." The court, by way of dictum, suggested that vicarious liability might be implied under the 1934 act which, unlike the Investment Companies Act, makes controlling persons jointly and severally liable.Id. at 917 . Section 20(a) of the 1934 act provides for a defense in cases where "the controlling person acted in good faith and did not ... induce the act ... constituting the violation." 48 Stat. 899 (1934), 15 U.S.C. $\$ 78 t$ (a) (1958). Whether it creates presumptive vicarious liability by making directors as such controlling persons is unclear. 2 Loss 781-82. The Investment Company Act negatives express vicarious liability by defining control to exclude "power . . . solely the result of an official position with such company." 54 Stat. 791 (1940), 15 U.S.C. $\$ 80(a)(2)(a)(9)(1958)$. See also Brown v. Bullock, 194 F. Supp. 207, 241 (S.D.N.Y. 1961); 3 Loss 2027-28.

1892 Loss 944 . Section 32(a) of the act provides for fines up to $\$ 10,000$ and imprisonment up to two years, "but no person shall be subject to imprisonment . . . for the violation of any rule if he proves that he had no knowledge of such rule." 
cause of action for damages as well as for rescission. 190 Similar results have been reached under other sections of the securities acts. ${ }^{191}$ This result is not surprising since the liability established by 29 (b) is as much expressed as implied. State courts applying blue sky laws have allowed suits for rescission of illegal contracts even where express voidability provisions were lacking. 192 The conclusion that section 29 (b) affords a private remedy is reinforced by the language of a 1938 amendment to the provision declaring that "no contract shall be deemed to be void by reason of this subsection in any action maintained in reliance upon this subsection," by purchasers from brokers violating section 15(c)(1), "unless such action is brought within one year."193 A suit under a contract rationale differs from a tort suit in a number of respects. Since the suit is on the contract, privity, or a third-party beneficiary relationship, is required.194 Section 29(b), therefore, cannot readily be applied to exchange transactions. Limitations periods for tort and contract actions may differ 195 and differences may also exist with respect to measure of damages 196 or survivability and assignability of actions. 197

Section 27 of the Exchange Act confers on the federal courts exclusive jurisdiction "of all suits in equity and actions at law brought to enforce any liability or duty" created by the act or rules under it. It is similar in its language to

190 E.g., Kardon v. National Gypsum Co., 69 F. Supp. 512 (E.D. Pa. 1946) (alternate ground) (applying rule 10b-5). See also Coburn v. Warner, 110 F. Supp. 850 (S.D.N.Y. 1953) (rule 15 cl-4); Osborne v. Mallory, 86 F. Supp. 869 (S.D.N.Y. 1949) $\$ 17$ (a); Geismar v. Bond \& Goodwin, Inc., 40 F. Supp. 876 (S.D.N.Y. 1941) applying § 15(c)(1).

191 Section 26(b) of the Holding Company Act, 49 Stat. 835 (1935), 15 U.S.C. $\$ \S 79(b)$, and $\S 47$ (b) of the Investment Company Act, 54 Stat. 845 (1940), 15 U.S.C. $\$ 80 a-56(b)$ (1958) are virtually identical. Goldstein v. Groesbeck, 142 F.2d 422 (2d Cir.), cert. denied, 323 U.S. 737 (1944), is the leading case under the Holding Company provision; Schwartz v. Bowman, 156 F. Supp. 361 (S.D.N.Y. 1957) appeal dismissed sub nom. Schwartz v. Eaton, 264 F.2d 195 (2d Cir. 1959). See also Brown v. Bullock, 194 F. Supp. 207, 231 (S.D.N.Y. 1961), the leading case under the Investment Company Act. An action for damages as well as for rescission has been implied under the voidability provision of the California blue sky statute. Auslen v. Thompson, 38 Cal. App. 2d 204, 101 P.2d 136 (Dist. Ct. App. 1940).

1923 Loss 1667-81. See Pollak v. Staunton, 210 Cal. 656, 293 Pac. 26 (1930) (statute); Vercillini v. V.S.I. Realty Co., 158 Minn. 72, 196 N.W. 672 (1924) (no statute); Kenalos v. H. V. Greene Co., 81 N.H. 426, 128 Atl. 335 (1925). Most state statutes expressly give a right of rescission. Some expressly exclude implied liability. See e.g., UNIFORM SECURITIES ACT $\$ 410(\mathrm{~h})$.

193 See 3 Loss 1760.

194 Cf. Brown v. Bullock, 194 F. Supp. 207, 229-30 (S.D.N.Y. 1961): "Privity of contract between the plaintiffs and the defendants is not a fixed condition precedent to the implication of a private [tort] remedy for a statutory violation that injured the plaintiffs, members of the protected class. ... It is an evidentiary fact to be considered in conjunction with other material facts in determining whether the relationship (such as it is) between the plaintiff and the defendants and the nature of the particular acts .... involve the duty created by the statute .... The relationship between the plaintiffs and the defendants, the nature of the defendants' participation in the challenged transactions, and the plaintiffs' reliance upon the defendants' acts may vary."

1953 Loss $1773-76$.

196 Id. at 1793-95.

197 Id. at 1817-18. 
provisions of the Securities 198 and Investment Company ${ }^{199}$ Acts which confer concurrent jurisdiction upon federal courts. The provisions of section 44 of the Investment Company Act have been used as an argument for implied civil liability. Since the SEC can only bring equity suits and there are separate provisions for criminal proceedings, it has been suggested that "the other elements in section 44 must refer to appropriate private actions and suits . . . to enforce any liability created by the act." 200 But this argument is specious since both the Investment Company and Securities Exchange Acts contain express provisions for civil liability to which the jurisdictional clauses apply.201 Support for implied civil liability must therefore be found in common-law tort concepts and in the language of section 29(b) and its 1938 amendments. The argument for civil liability under section 29(b) seems to be incontrovertible. The use of the maxim expressio unius est exclusio alterius as an argument against civil liability has gained little favor with the Supreme Court202 in its earlier ventures into the complexities of securities legislation, and in any case cannot be used to reject liabilities recognized by section $29(\mathrm{~b})$ and its amendments.

The scope of the civil liabilities in relation to sales by insiders has been the subject of elaborate discussion ${ }^{203}$ and much controversy. The carefully delineated, express liabilities contained in sections 11 and 12 of the Securities Act have led a number of commentators to deny the existence of any implied civil action in favor of buyers of stock under either rule 10b-5 or section 17(a) of the Securities Act.204 One commentator has expressed the fear that "the continued denigration of the buyer's express remedies under the 1933 act in favor

19848 Stat. $86-87$ (1933), as amended, 15 U.S.C. $\$ 77(v)(a)$ (1958). No reference to suits in equity is made in this provision.

19954 Stat. 844 (1940), 15 U.S.C. $§ 80($ a) 43 (1958).

200 Brown v. Bullock, 194 F. Supp. 207, 246 (S.D.N.Y. 1961).

${ }^{201}$ E.g., Securities Exchange Act, $\S \S 9(\mathrm{e}), 16(\mathrm{~b}), 18(\mathrm{a}), 48$ Stat. 890, 896, 897 (1934), 15 U.S.C. $\$ \S 78(\mathrm{i})(\mathrm{e}), 78 \mathrm{p}(\mathrm{b})$, as amended, $78 \mathrm{r}(\mathrm{a})(1958)$; Investment Company Act, $\S 30(\mathrm{f})$, 54 Stat. 837 (1940), 15 U.S.C. $\$ 80$ a-29(f) (1958).

202 SEC v. C. M. Joiner Leasing Corp., 320 U.S. 344 (1943). See Fratt v. Robinson, 203 F.2d 627 (9th Cir. 1953). Compare Howard v. Furst, 238 F.2d 790 (2d Cir. 1956), cert. denied, 353 U.S. 937 (1957).

203 See particularly Latty, The Aggrieved Buyer or Seller or Holder of Shares in a Close Corporation Under the S.E.C. Statutes, 18 LAW \& CoNTEMP. ProB. 505 (1953); 3 LosS $1778-92$.

2043 Loss 1790-91; Fischman v. Raytheon Mfg. Co., 9 F.R.D. 707 (S.D.N.Y. 1949), rev'd, 188 F.2d 783 (2d Cir. 1951); Rosenberg v. Globe Aircraft Co., 80 F. Supp. 123 (E.D. Pa. 1948); Montague v. Electronic Corp., 76 F. Supp. 933 (S.D.N.Y. 1948). Cf. the attitude of the SEC as expressed in 1952: "While it is true that section 10(b) of the Exchange Act and rule $X-10 B-5$ thereunder involves fraud in both the purchase and the sale, I believe that section 17 of the 1933 act adequately covers the field with respect to sales, with respect to any person selling. . . . I am not saying it does not apply to sales, but in practical application it directs itself to purchases in our application of the rule." Hearings before a Subcommittee of the House Committee on Interstate and Foreign Commerce, 82d Cong., 2d Sess., Pt. 1, at 724 (1952) (testimony of Peter T. Byrne). 
of rule 10b-5 and even section 17(a) of the 1933 act itself, may persuade the Supreme Court, which has yet to consider any implied remedy under the SEC statutes-to throw its collective hands up and the Kardon doctrine out."'205 Other views would limit the application of implied liability to practices for which no express action in favor of buyers is available,206 or would allow an implied action, with its generous limitations period and damage rules, only where the proof available exceeds that needed under the express provisions with their diluted scienter requirement. ${ }^{207}$ But the courts have been reluctant to so limit buyers' actions, and have allowed buyers to sue under both 17(a) ${ }^{208}$ and $10 \mathrm{~b}-5^{209}$ even where an express remedy is provided by the Securities Act. The express actions included in the Exchange Act itself have given the courts little difficulty, since they do not purport to establish a general remedy for fraud. 210

The most vexing problems presented by the implied liabilities relate to their source rather than their scope. It seems clear that any liability under a void contract theory arises directly from section 29(b), and hence that such contract actions are maintainable throughout the nation and may be brought in the federal courts without regard to diversity of citizenship.211 But liability under a tort theory presents more difficult problems of federal jurisdictionproblems that have been extensively discussed elsewhere 212 and that must be deemed beyond the scope of this comment.

A question also exists as to whether rule $10 \mathrm{~b}-5$ authorizes derivative suits on behalf of a corporation brought by stockholders who were not themselves defrauded. In the Slavin ${ }^{213}$ and Birnbaum ${ }^{214}$ cases the courts refused to enter-

2053 Loss 1790.

206 Latty, supra note 203.

207 Joseph v. Farnsworth Radio \& Television Corp., 198 F.2d 883 (2d Cir. 1952) (Frank, J., dissenting).

${ }^{208}$ E.g., Osborne v. Mallory, 86 F. Supp. 869 (S.D.N.Y. 1949).

209 Ibid.; Ellis v. Carter, 291 F.2d 270 (9th Cir. 1961); Matheson v. Armbrust, 284 F.2d 670 (9th Cir. 1960), cert. denied, 365 U.S. 870 (1961); Fischman v. Raytheon Mfg. Co., 188 F.2d 783 (2d Cir. 1951); Dauphin Corp. v. Redwall Corp., 201 F. Supp. 466 (D. Del. 1962); Texas Continental Life Ins. Co. v. Bankers Bond Co., 187 F. Supp. 14 (W.D. Ky. 1960). $C f$. Thiele v. Shields, 131 F. Supp. 416 (S.D.N.Y. 1955) (applied to municipal bond transactions specifically exempt under express provisions). This view is currently supported by the SEC. See Cary, Book Review, 75 Harv. L. Rev. 857, 861-62 (1962).

210 Fratt v. Robinson, 203 F.2d 627 (9th Cir. 1953).

211 Geismar v. Bond \& Goodwin, Inc., 40 F. Supp. 876 (S.D.N.Y. 1941). Cf. Saminsky v. Abbott, CCH FED. SEC. L. REP. I 91,047 (Del. Ch. 1961) (recovery in state court for void contract claims brought under $\$ 47(\mathrm{~b})$ of Investment Company Act).

2122 Loss, 986-1013; Note, 48 Colum. L. Rev. 1090 (1948). See Dann v. StudebakerPackard Corp., 288 F.2d 201 (6th Cir. 1961); Remar v. Clayton Securities Corp., 81 F. Supp. 1014 (D. Mass. 1949).

213 Slavin v. Germantown Fire Ins. Co., 174 F.2d 799, 807 (3d Cir. 1949) (where corporate agent defrauded assignors of stock warrants, "the right of redress, if any, belongs to the as- 
tain such suits, concluding that the Exchange Act is not a means for holding directors to fiduciary standards in their dealings with the corporation itself. This is not to say that the corporation has no rights under the rule as to dealings in its own stock. A controversial recent case ${ }^{215}$ has allowed a derivative suit against persons who had defrauded a corporation when buying newly issued stock from it. This case has been much criticized. But it seems essentially correct. A corporation is entitled to the same rights under the rule as any other trader.216 Any other result would in effect declare that misrepresentation and fraudulent nondisclosure by a purchaser of stock are permissible so long as the victim is the issuer itself. The corporation's appropriate rights under the rule are thus essentially those of an investor since it has rights against those who by deceit and nondisclosure defraud it, but not against those who manage and manipulate it for their own ends.

Under the SEC proxy rules, similar results have been reached. Though at first courts were inclined to question whether suits might be brought under the rules by persons not themselves fraudulently induced to give proxies, ${ }^{217}$ it was concluded in the recent Dann ${ }^{218}$ case that the rules were designed for the protection of corporations as well as insurgent shareholders. A representative suit by shareholders was thus allowed as a matter of "federal common law."219 But this federally-created derivative right was held to encompass only such prospective and declaratory relief as might prevent the perpetration of fraud by outsiders upon the corporation. Once control and management had passed to a new group, the proxy rules could not supply a means for redressing the

signors, and not to the corporation."). Cf. Norris Tool \& Machine Co. v. Rosenlund, 355 Pa. 560, 50 A.2d 273 (1947) (denying the assignor a common-law right of action).

${ }^{214}$ Birnbaum v. Newport Steel Corp., 193 F.2d 461 (2d Cir. 1952) (sale of controlling interest not actionable at suit of shareholders not buying or selling since act is not a remedy for fraudulent mismanagement). See 3 Loss 1468. Cf. Perlman v. Feldmann, 219 F.2d 173 (2d Cir.), cert. denied, 349 U.S. 952 (1955).

215 Hooper v. Mountain States Securities Corp., 282 F.2d 195 (5th Cir. 1960), criticized in 13 Stan. L. REv. 378 (1961). An earlier case also held that fraud as to the value of consideration paid for securities was actionable under rule 10b-5: Errion v. Connell, 236 F.2d 447 (9th Cir. 1956).

216 A corporation defrauded in its dealings in another corporation's stock may of course sue. See Slavin v. Germantown Fire Ins. Co., 174 F.2d 399 (3d Cir. 1949) (dictum); 13 STAN. L. REv. 378 (1961).

217 Howard v. Furst, 238 F.2d 790 (2d Cir. 1956), cert. denied, 353 U.S. 937 (1957).

218 Dann v. Studebaker Packard Corp., 288 F.2d 201 (6th Cir. 1961).

219 The court attempted to distinguish the Howard case, 238 F.2d 790, on the basis that the suit there was derivative rather than representative and that the right involved in Dann was not a corporate right but rather a shareholder's "right to the free exercise of the corporate franchise." 288 F.2d at 210 . This distinction was made even though the plaintiff was not himself fraudulently induced to give a proxy. But the court conceded that its rules "are merely legal formalisms in which the court elects to clothe its choice of the underlying policy considerations upon which the real basis of decision must rest." 288 F.2d at 211. 
grievances of stockholders against the management of the corporation.220 The claim for retrospective relief was held to constitute a separate cause of action, not created or governed by "federal common law" and hence not maintainable in the federal courts, at least without recourse to the doctrine of pendent jurisdiction, which the court refused to apply. The court in Dann also rejected without discussion the argument that activities of directors installed as a result of improper proxy solicitations might be rescinded under section 29(b).221 However, a recent case under the Investment Company Act proxy rules allowed rescission of such transactions, distinguishing Exchange Act cases on the persuasive basis that "the 1940 Act operates as a corporation law for investment companies. In sharp contrast, the 1934 Act . . . regulates one phase-the purchase and sale of corporate securities." 222 But within this phase of activity, at least, the case for civil liability under Exchange Act rules seems clear. The rule of Cady, Roberts may ultimately be binding in private as well as public law.

6. Cady, Roberts and Administrative Law.-Because of the probability of civil liability, any extension of the scope of rule $10 \mathrm{~b}-5$ is of great importance not only in administrative and criminal proceedings but also to the common law of securities trading. Moreover, the continuing possibility that the SEC may be empowered by decision or statute to enforce restitution to private parties enhances the significance of interpretations of its rules.223

The opinion in Cady, Roberts should prove a rather durable pronouncement. Its declarations as to facts that need be disclosed and as to privity do not go substantially beyond the most advanced common-law view. In charging

220 Similar conclusions have been reached under the Holding Company Act. See Goldstein v. Groesbeck, 142 F.2d 422 (2d Cir. 1944).

221 Note, 75 HaRv. L. Rev. 637, 639 (1962).

222 Brown v. Bullock, 194 F. Supp. 207, 233 (S.D.N.Y.), aff'd without consideration of the point, 294 F.2d 415 (2d Cir. 1961). But compare Brouk v. Managed Funds, Inc., 286 F.2d 901, 908-11 (8th Cir. 1961).

223 See generally 3 Loss 1824-29. For expressions of SEC policy as to enforcement of restitution under 17(a) and 10b-5, see Hearings Before a Subcommittee of the House Interstate and Foreign Commerce Committee, 82d Cong., 2d Sess., at 724-25 (1952) (testimony of Peter T. Byrne); Cary, Book Review, 75 HARv. L. REv. 857, 861 (1962). The government has been allowed to sue for restitution to private parties in cases under the Rent Control and Fair Labor Standards Acts. See Mitchell v. Robert De Marco Jewelry Inc., 361 U.S. 288 (1960) and cases there cited. But cf. United States v. Hutchinson, 240 F.2d 918 (9th Cir. 1956) (no enforcement of restitution under Food and Drug Act); Cherner v. Transitron Corp., 201 F. Supp. 934 (D. Mass. 1962) (dictum). Informal enforcement of restitution by threat of criminal prosecution is common. 3 Loss 1824 n.469.

It is not altogether clear whether a private party may vindicate the rights of other defrauded traders in a class action under the rule. See 3 Loss 1819-24. One district court refused to use its discretion to canvass possible participants in such an action. See Cherner v. Transitron Corp., supra. Cf. Allen v. Hyatt, 30 T.L.R. 444 (1914). See also SEC v. Bennett \& Co., CCH FED. SEC. L. REP. If 91,172 (D.N.J. 1962) (refusal to appoint equity receiver of solvent corporation for benefit of potential private suitors). Compare Oppenheimer v. F. J. Young \& Co., 144 F.2d 387 (2d Cir. 1944) (A. N. Hand, J.); Mills v. Sarjem Corp., 133 F. Supp. 753, 762-63 (D.N.J. 1955), and cases there cited. 
a person receiving information from an insider, the decision has gone beyond the common law, though not without support in some cases under it. But the SEC is not limited to common-law doctrines in construing its fraud rules. ${ }^{224}$ Its construction of the rules of course is reviewable by the courts. Since section 10(b) of the Exchange Act is not self-executing, 225 the Commission cannot argue that its decision is valid as an order implementing the statute if not valid as an application of rule 10b-5.226 Thus the fact that the Cady, Roberts decision operates prospectively only makes little difference as to the validity of its principle in later cases.227 Since it cannot be sustained as an order, the courts must ultimately decide whether it falls within rule $10 \mathrm{~b}-5$.

The principle announced, however, is one that may invite substitution of judgment on judicial review. The generality of the Cady, Roberts rule228 and the relatively equal qualifications of the courts and Commission in relation to general questions of fiduciary duty229 suggest that the courts may be inclined to make their own policy judgments on appeal. On the other hand, the Commission has been viewed as having been delegated unusually broad powers to prevent fraud, and a different result will probably obtain. 230 The courts are

224 Ellis v. Carter, 291 F.2d 270, 274 (9th Cir. 1961); Hooper v. Mountain States Securities, Inc., 282 F.2d 195, 201 (5th Cir.), cert. denied, 365 U.S. 814 (1961) (rule 10b-5); Norris \& Hirschberg v. SEC, 177 F.2d 228 (D.C. Cir. 1948); Charles Hughes \& Co. v. SEC, 139 F.2d 434, 437 (2d Cir.), cert. denied, 321 U.S. 786 (1943); Coplin v. United States, 88 F.2d 652, 658 (9th Cir.), cert. denied, 301 U.S. 703 (1937) (\$ 17(a)); Speed v. Transamerica Corp., 99 F. Supp. 808, 829, 831 (D. Del. 1951). See also UNIFORM SECURITIEs Act $\$ 401$ (d) (" 'Fraud,' 'deceit,' and 'defraud' are not limited to common law deceit"). But compare SEC v. Capital Gains Research Bureau, 300 F.2d 745 (2d Cir. 1961) (2-1 panel opinion, one judge concurring only in the result).

225 The rule prohibits the use of "any manipulative or deceptive device or contrivance in contravention of such rules and regulations as the commission may prescribe."

226 Compare SEC v. Chenery Corp., 332 U.S. 194 (1947).

227 Where orders operate retroactively, "such retroactivity must be balanced against the mischief of producing a result which is contrary to a statutory design." Id. at 203.

2284 DAVIS, ADMINISTRATrve LAW $\S 30.11$ (1958).

229 But see SEC v. Chenery Corp., 332 U.S. 194, 207 (1947), criticized in 4 DAvs, op. cit. supra note 228, at 246: "Although other aspects of the case could justify the narrow scope of review, the idea of comparative qualifications alone surely does not. The problem of the limits of the fiduciary principle is a broad and fundamental one with which the Supreme Court is fully competent to deal." Compare SEC v. Cogan, 201 F.2d 78, 86 (9th Cir. 1952): "For many generations the courts of equity have been dealing with these problems of fiduciary duty. . . . The . . . judge ... was as well qualified to pass upon . . . standards of ... conduct . . . as was the Commission."

230 See SEC v. Chenery Corp., supra note 229 (policy decision held not delegated to Commission). Cf. 4 DAvis, op. cit. supra note 228 , at 249: "Just as the broader review of interpretative rules depends upon lack of delegation of power to the agency, and just as the narrower review of legislative rules depends upon a delegation of power to the agency, so the scope of review of administrative adjudication often depends upon delegation or the lack of it." For a suggestion that the SEC fraud rules are essentially interpretative, see Blair-Smith, Forms of Administrative Interpretation Under the Securities Laws, 26 IOWA L. REv. 241, 267 (1940). But agencies are usually accorded broad discretion in formulating remedies for law violations, since "Congress could not catalogue all the devices and strategems for circum- 
also reluctant to upset an agency's interpretation of its own regulations, 231 even though such interpretations do not gain added force from the agency's unexercised power to amend its rules.232 Thus the Commission should not be held to have exceeded its authority under the rule, even if the decision is read broadly.

The opinion, however, raises questions of administrative method, not merely the jurisdictional questions that we have considered. The objection that "absent from the Commission's decision is any statement as to what constitutes fraud as used in Rule 10b-5"233 will probably not impress the courts, which have themselves been notably reluctant to define fraud.234

It would also seem clear that an agency can, by opinion as well as by rule, make extensions in prior law beyond those necessary to decide the case before it.235 The courts, however, may be unwilling, on review, to place their imprimatur on administrative opinions which, in addition to deciding the case

venting the policies of the act." Phelps Dodge Corp. v. NLRB, 313 U.S. 177, 194 (1941). Considerations of this sort may justify a flexible fraud rule. Compare note 80 supra. See also American Power \& Light Co. v. SEC, 329 U.S. 90, 112 (1946): "The relation of remedy to policy is pecularly a matter for administrative competence'... . [O]nly if the remedy chosen is unwarranted in law or is without justification in fact should a court attempt to intervene in the matter."

231 Retroactivity can alter this reluctance. See 4 DAVIS, op. cit. supra note 228, at 261.

2324 DAvis, op. cit. supra note 228, at 462 . No effort to amend was made in Cady, Roberts. Cf. Gibson Wine Co. v. Snyder, 194 F.2d 329 (D.C. Cir. 1952). It is sometimes intimated that the availability of the rule making power should cut down agency discretion in adjudication. SEC v. Chenery Corp., 332 U.S. 194, 202 (1947); SEC v. Capital Gains, Inc., 300 F.2d 745 (2d Cir. 1961). This argument. can be made on the basis that the rule-making process involves detailed hearings, avoids retroactivity and is not circumscribed by separation of functions within the agency. Baker, Policy by Rule or Ad Hoc Approach-Which Should it Be?, 22 LAW \& ConTEMP. ProB. 658, 664 (1957). But the last two arguments at least are not relevant to Cady, Roberts. Participation by the Commission's staff in the preparation of the opinion was one of the conditions of the offer of settlement. SEC Securities Exchange Act Release No. 6668, at 2 n.3.

233 Daum \& Phillips, The Implications of Cady, Roberts, 17 Bus. LAw. 939, 947 (1962).

234 See note 80 supra. Cf. Lleweleyn, JURISPRUDENCE 407 n.1 (1962): "Peculiarly difficult to reach by regulation are those cases where executives, directors, etc., exercise discretion in their own interests, in opposition to the interests of the group they supposedly represent. This is the problem of government, and we seem to be quite as far from solving it in the business and social fields as we are in the more purely political." See also Kaplan, Conflict of Interests: Corporate Directors, 50 ILL. BAR J. 1072, 1088 (1962): "Though it may not satisfy one's sense of simplicity and symmetry to refrain from laying down broad prophylactic rules, it is the writer's belief that the proper objectives of such rules, namely-the prevention of the abuse of position for personal benefit - can best be achieved by a flexible standard in which the propriety of an insider's conduct and its fairness in the light of specific and particular corporate interests is the ultimate criterion. ... This calls for the application of ethical standards ... to particular sets of fact."

2352 Davis, op. cit. supra note 228 , at $\S 17.08$. The suggestion of the panel opinion in the Capital Gains case, 300 F.2d 745 (2d Cir. 1962), that any significant expansion of the law must be made by rule, even where the administrative holding does not go beyond that necessary to decide the case at hand seems clearly untenable where a statute or rule is selfexecuting. 
at hand, contain broad and unsupported dicta.236 If judicial assent to administrative generalizations is sought, the courts may insist either that the generalization be made by rule or that it be supported by adequate reasons and findings. Since courts lack the power, on review, to substitute their own findings or reasons for those of an agency with primary jurisdiction, 237 opinions such as that in Cady, Roberts may frequently be remanded. Where agencies desire to expand prior law, they should either let a narrow holding in a single case serve as signal, or should clarify both the scope of an expansion and the basis upon which it rests. That discipline, more severe than that imposed on courts themselves, may be the price exacted for the grant to agencies of discretionary power within limited jurisdictions.

7. Conclusion.-The Cady, Roberts decision, in holding a trader liable for nondisclosure in the absence of "special facts" or misrepresentations, announces a rule that does not go far beyond prior law, though subsection 3 rather than subsection 2 of the rule would seem the logical vehicle for its expansion. The application of the rule to persons in a bilateral relationship with insiders likewise finds more support in prior law than may commonly be supposed. Literal use of the rule to charge "any person" receiving information from an insider would possess advantages in establishing standards of fair dealing meaningful to traders in the market acting in a wide variety of situations. The use of such a rule probably should be qualified where information was innocently acquired or where there was no clear showing that it influenced trading decisions. Cases involving the acquisition and use of trade secrets, though not directly analogous, offer useful guidance in this sphere.

Application of the rule to exchange transactions and transactions involving nonshareholders finds an adequate basis in fiduciary principles. The possibility of civil liability in some such transactions should not be excluded, since at common law liability for fraud is not bounded by a strict privity rule. Privity, rather than proof of damage, should continue to serve as the limiting principle in suits where nondisclosure, rather than misrepresentation, supplies the basis of liability.

While accepted tort principles demand the imposition of civil liability under the rule, requirements of injury to a protected interest should prevent the use of the rule as a remedy for corporate mismanagement as opposed to trading frauds. The Cady, Roberts holding does not exceed the SEC's jurisdiction under the rule, since the Commission is not limited by common-law fraud standards. The scope and basis of the decision should be clarified, however, if the courts are to make its rule fully effective as an alteration of the administrative and common law of securities trading.

236 See, e.g., Mac Robbins \& Co., SEC Securities Exchange Act Release No. 6462 (Feb. 6, 1961), supplemented, SEC Securities Exchange Act Release No. 6498 (March 20, 1961), remanded, Berko v. SEC, 297 F.2d 116 (2d Cir. 1962); Kahn v. SEC, 297 F.2d 112 (2d Cir. 1961), on remand, Mac Robbins \& Co., CCH FED. SEC. L. REP. T 76,853 (1962).

2372 DAvIs, op. cit. supra note 228 , at $\$ 16.12$. 